\title{
Effects of Sleep Deprivation by Olfactorily Induced Sexual Arousal Compared to Immobilization Stress and Manual Sleep Deprivation on Neuromessengers and Time Keeping Genes in the Suprachiasmatic Nuclei and Other Cerebral Entities of Syrian Hamsters-An Immunohistochemical Study
}

\author{
Christian Knöchel ${ }^{1, \dagger}$, Hagen Frickmann ${ }^{2,3,+} \mathbb{D}$ and Frank Nürnberger ${ }^{4, *}$ \\ 1 Vitos Clincis of Forensic Psychiatry Eltville, 65346 Eltville, Germany; Christian.knoechel@vitos-rheingau.de \\ 2 Department of Microbiology and Hospital Hygiene, Bundeswehr Hospital Hamburg, \\ 20359 Hamburg, Germany; hagen_frickmann@hotmail.com or frickmann@bnitm.de \\ 3 Institute for Medical Microbiology, Virology and Hygiene, University Medicine Rostock, \\ 18057 Rostock, Germany; hagen.frickmann@med.uni-rostock.de \\ 4 Institute for Anatomy II, Goethe-Universität Frankfurt am Main, 60590 Frankfurt am Main, Germany \\ * Correspondence: f.nuernberger@em.uni-frankfurt.de \\ check for
updates
}

Citation: Knöchel, C.; Frickmann, H.;

Nürnberger, F. Effects of Sleep

Deprivation by Olfactorily Induced

Sexual Arousal Compared to

Immobilization Stress and Manual

Sleep Deprivation on

Neuromessengers and Time Keeping

Genes in the Suprachiasmatic Nuclei

and Other Cerebral Entities of Syrian

Hamsters-An Immunohistochemical

Study. Int. J. Environ. Res. Public

Health 2021, 18, 9169. https://

doi.org/10.3390/ijerph18179169

Academic Editors: Paul

B. Tchounwou and Ari Shechter

Received: 7 June 2021

Accepted: 27 August 2021

Published: 31 August 2021

Publisher's Note: MDPI stays neutral with regard to jurisdictional claims in published maps and institutional affiliations.

Copyright: () 2021 by the authors. Licensee MDPI, Basel, Switzerland. This article is an open access article distributed under the terms and conditions of the Creative Commons Attribution (CC BY) license (https:// creativecommons.org/licenses/by/ $4.0 /)$.

\begin{abstract}
We investigated the effects of sexual arousal induced by olfactory stimuli on the expression of neuromodulators, neurotransmitters and sexual steroid receptors in the suprachiasmatic nucleus (SCN, the circadian pacemaker of mammals) and other cerebral entities of Syrian hamsters (Mesocricetus auratus) compared to manual sleep deprivation and immobilization stress. The hamsters kept under a 12:12 hours (h) light:dark cycle were deprived of sleep by sexual stimulation, gentle manual handling or immobilization stress for $1 \mathrm{~h}$ at the beginning of the light phase and subsequently sacrificed at zeitgeber time 01:00, respectively; for comparison, hamsters were manually sleep deprived for 6 or $20 \mathrm{~h}$ or sacrificed after completing a full sleep phase. As demonstrated by immunohistochemistry, apart from various alterations after manual sleep deprivation, sexual stimulation caused down-regulation of arginine-vasopressin (AVP), vasointestinal peptide (VIP), serotonin (5-HT), substance P (SP), and met-enkephalin (ME) in the SCN. Somatostatin (SOM) was diminished in the medial periventricular nucleus (MPVN). In contrast, an increase in AVP was observed in the PVN, that of oxytocin (OXY) in the supraoptic nucleus (SON), of tyrosine-hydroxylase (TH) in the infundibular nucleus (IN), and dopamine beta-hydroxylase (DBH) in the A7 neuron population of the brain stem (A7), respectively. Testosterone in plasma was increased. The results indicate that sexual arousal extensively influences the neuropeptide systems of the SCN, suggesting an involvement of the $\mathrm{SCN}$ in reproductive behavior.
\end{abstract}

Keywords: sexual arousal; sleep deprivation; Syrian hamster; suprachiasmatic nucleus; aphrodisin; pheromone; neuropeptide; neurotransmitter

\section{Introduction}

Different modulator and transmitter systems of various hypothalamic nuclei are involved in sexual control: arginine-vasopressin (AVP), dopamine, oxytocin (OXY), and substance P (SP) next to sexual steroids facilitate sexual behavior [1-5], whereas neuropeptide Y (NP Y), somatostatin (SOM), endogenous opioids such as met-enkephalin (ME), serotonin (5-HT = 5-hydroxy-tryptamin) and gamma-amino butyric acid (GABA) express inhibitory influences on sexual activity [6-10]. Most of these messengers are observed in the suprachiasmatic nuclei (SCN), which are located in the anterior hypothalamus. Although these nuclei predominantly represent the master circadian pacemakers in mammals, which rule the cycle of sleep and alertness [11], the SCN may also control particular aspects of 
sexual behavior, which is further supported by the occurrence of GRP and VIP within this entity. The latter peptides are involved, at least, in the peripheral control of reproductive organs [12,13], although some reports on central nervous involvement are available [14].

The main output projections of the SCN terminate in the magnocellular paraventricular nucleus (PVN), which conveys biorhythmic cues to the peripheral organism via the autonomic nervous system and the endocrine axis [15]. Furthermore, the SCN regulates the neurons of the supraoptic nucleus (SON), the main source of diurnally-rhythmically released OXY [16]. In addition, the SCN is influenced by somatostatinergic afferences from the medial periventricular nucleus (MPVN) [17] and serotoninergic afferences from the dorsal raphe nucleus [18,19], the latter itself being influenced by norepinephrinergic afferences from the brain stem [20]. Norepinephrinergic afferences are known to directly or indirectly influence the circadian regulation of arousal [21].

To elucidate the stability of the diurnal rhythmic alterations of the above-mentioned messenger systems, we experimentally affected the natural diurnal rhythm by sleep deprivation at the beginning of the main sleep phase of Syrian hamsters which starts in the early light phase. We studied the effect of sleep deprivation [22] on selected neuropeptide and neurotransmitter systems in comparison to animals that could sleep ad libitum. In particular, we compared such effects after gentle manually or stress-induced sleep deprivation with effects of a particular kind of reproductive sleep deprivation, i.e., the stimulation of sexual behavior by pheromones and the presence of females.

This type of sexual sleep deprivation in male Syrian hamsters was induced by showing female hamsters in adjoining cage compartments combined with exposition to the pheromone aphrodisin, a soluble glycoprotein of the vagina of hamsters proven to stimulate mating behavior in male hamsters. Dimeric recombinant aphrodisin molecules bind to dimethyl-disulfide which acts at pheromone receptor neurons in the basal compartment of the vomeronasal epithelium axonally connected with the caudal region of the accessory olfactory bulb [23-25].

In order to distinguish the effects of sexually driven sleep deprivation from that of alternative waking signals and the pheromone effects alone, we compared the sexually stimulated group with additional control groups, one being deprived of sleep for the same interval and during the same diurnal phase by gentle manual handling, another one by pheromone exposition alone, and a third one by the aversive stimulus of immobilization stress, respectively. The scientific goals were the induction of sexual arousal and the observation of specific patterns on precisely localized neurotransmitter and neuropeptide reactivity.

The assessment was focused on sleep deprivation by sexual arousal rather than on sexual arousal solely due to the assumption that sexual arousal-induced effects may be more obvious during diurnal phases of tiredness or inactivity rather than during periods of natural alertness. Therefore, the experiments were performed during the resting period and not during the typical mating period usually occurring during the night phase.

\section{Materials and Methods}

\subsection{Laboratory Animals}

Fifty-three sexually naïve adult male Syrian golden hamsters (Mesocricetus auratus) were obtained from Charles River (Sulzfeld, Germany) at the age of 3 weeks and kept in groups of five animals (litter mates) per cage. Free access to food (rat pellets) and water was guaranteed. Constant temperature of $20^{\circ} \mathrm{C}$ and a day-night-periodicity of $12 \mathrm{~h}$ light and $12 \mathrm{~h}$ darkness were provided for at least 8 weeks (lights on 07:00 = zeitgeber time [ZT] 00:00). This light regimen was chosen since the hamsters develop their sexual maturity under those conditions; their natural circadian period length $\tau$ is approximately $23 \mathrm{~h}$. All hamsters were tamed to avoid unintended stress-specific effects. The taming was achieved by frequent manual interactions, i.e., lifting the animals out of the cages, soft stroking, and gentle touching. Principles of laboratory animal care and specific national laws were followed in line with the German standards when the experiments were performed between 2003 and 
2005. In detail, all experiments were in accordance with a protocol approved by the Policy on Ethics, as approved by the Society for Neuroscience, and which was consistent with Federal guidelines and the European Communities Council Directive.

\subsection{Pre-Tests Regarding the Animals' Behavior}

In order to verify the diurnal sleep cycle and the main diurnal sleep phase of the Syrian hamsters used in the present investigation, their sleeping behavior was observed during the entire diurnal cycle prior to the experiments described below. The pre-test studies also included the observation of the activity patterns of the hamsters exposed to olfactory stimulation with pheromone and optical stimulation with female hamsters during the pre-noon light phase, i.e., the main diurnal sleep phase. Furthermore, the behavior of the hamsters during prolonged sleep deprivation $(6 \mathrm{~h}, 20 \mathrm{~h})$ was observed. We decided not to show activity or sleep profiles, since our animals did behave according to the descriptions published in the recent literature, cf., e.g., [26].

\subsection{Sexual Stimulation, Immobilization Stress, and Gentle Manual Handling}

The experiments were performed during the 12th week of life of the golden hamsters at a time when the animals were sexually mature but still naïve. Accordingly, social stress and obesity did not occur at that early stage of maturity. The cages - each containing four or five male hamsters which were kept together and knew each other (as litter mates) -were assigned to the experimental groups. All experiments were performed under conditions of bright light at the beginning of the light-phase.

For the pre-tests on the basic effects of sleep deprivation by gentle manual handling, a control group was defined which was allowed to sleep and sacrificed at zeitgeber time 05.00 at the end of their natural sleeping period. A short-term sleep deprivation group, which was sacrificed at the same time, was kept awake for the whole sleeping period by gentle manual handling starting $1 \mathrm{~h}$ prior to the onset of the light phase, resulting in a total of $6 \mathrm{~h}$ sleep deprivation. Furthermore, a prolonged sleep deprivation group, for which gentle manual handling started at zeitgeber time 09.00 of the day before, resulting in $20 \mathrm{~h}$ sleep deprivation before the animals were sacrificed at zeitgeber time 05.00, was added.

Because the sexual stimulation experiment (as described in detail below) failed to keep the animals awake for the whole sleeping period, the sacrificing time for the comparison of sleep deprivation due to gentle manual handling, exposition to pheromones alone, exposition to pheromones and females, and immobilization stress, respectively, was set at zeitgeber time 01.00 .

Accordingly, the sexual stimulation group consisted of animals that were deprived of sleep at the beginning of their main sleeping period starting at ZT 00:00 by sexual stimulation for $1 \mathrm{~h}$. The pheromone used for the olfactory stimulation consisted of a solution containing $\sim 35 \mathrm{mg} / \mathrm{L}$ recombinant aphrodisin produced in yeast cells [27]. This stock solution, which was supplemented with $1 \%$ yeast extract, $2 \%$ peptones, $100 \mathrm{mM} / \mathrm{L}$ potassium phosphate, $1.34 \%$ yeast mitogen base with ammonium sulfate and $0.5 \%$ methanol, was a donation of Privatdozent Dr. Hans-Jürgen Mägert and Dr. Michael Walden. Just before application in the experiment, $10 \mathrm{~mL}$ of dimethyl disulfide (DMDS $1 \mathrm{~g} / \mathrm{mL}$ ) was added to $500 \mathrm{~mL}$ of the aphrodisin-containing solution.

- Group 1, sexual stimulation with ahrodisin and females: A hamster cage (Makrolon cage type III) was divided in its centre by a double layer of flywire. Two cellulose balls soaked with the aphrodisin-DMDS-mixture were placed under the bedding of one area, five adult female hamsters (age $\geq 3$ months) in the other area. The female Syrian hamsters (purchased from Charles River, Sulzfeld, Germany) were kept under the same conditions as the males but completely separated in another room. According to literature, female hamsters are sexually sensible for one day each 4 to 7 days at median daily temperature of $15^{\circ} \mathrm{C}$ [28]. When the experiment started, five male hamsters were placed in the pheromone-containing compartment. They were able to see, hear and smell the females through the wire-netting without being able to 
physically contact them. The aphrodisin-DMDS-mix was additionally applied to the cage with a vaporizer. This experiment was performed twice, resulting in materials from 10 hamsters.

- Group 2, sexual stimulation with aphrodisin solely: The experimental setting of the pheromone-only group consisting of five hamsters was the same as described for group 1 with the exception that no female animals were present.

- Group 3, manual sleep deprivation: The manual sleep deprivation group was deprived of sleep by gentle manual handling whenever the hamsters tended to fall asleep during the same period of the diurnal phase starting at ZT 00:00. This group was subdivided into 10 animals sleep deprived for $1 \mathrm{~h}$ (ZT 00:00 to ZT 01:00, later referred to as group 3a (group 3a represents the principle control group for groups 1, 2 and 4 )), five hamsters sleep deprived for $6 \mathrm{~h}$ (ZT 23:00 to ZT 05:00, later referred to as group 3b) and nine animals sleep-deprived for $20 \mathrm{~h}$ (ZT 09:00 to ZT 05:00 of the following day, later referred to as group 3c). (Groups $3 b$ and $3 c$ were introduced for deciphering possible changes after different durations of sleep deprivation).

- Group 4, sleep deprivation by stress: Finally, the last comparison group was exposed to immobilization stress by nearly complete immobilization caused by wrapping them with extra strong scotch tape. The head remained unwrapped. Thus, ventilation was still guaranteed. All comparison groups for the sexual stimulation group were also sacrificed at zeitgeber time 01.00 .

- Group 5, sleep control: Nine hamsters were sacrificed after undisturbed sleep for $5 \mathrm{~h}$ at ZT 05:00. A further group studied after $1 \mathrm{~h}$ of sleep was not used, since there are no significant changes in comparison to $5 \mathrm{~h}$ of sleep, however, the experimental setup to prevent the effects of disturbed sleep after $1 \mathrm{~h}$ is rather complicated as shown in [29].

\subsection{Sample Acquisition and Preparation}

All hamsters were sacrificed by decapitation, either at ZT 01.00 to 01.15 or at ZT 05:00 to $05: 15$, depending on the experimental group. Blood was collected via a heparinized funnel (Liquemin ${ }^{\circledR}$, Hoffmann-La Roche AG, Basel, Switzerland) in EDTA tubes and centrifuged; plasma was separated and frozen at $-20{ }^{\circ} \mathrm{C}$. All brains were quickly dissected out of the skull, the hemispheres of the telencephalon were removed and the remaining brain tissue was immersion-fixed in Zamboni's solution (4\% paraformaldehyde plus 15\% saturated picric acid in $0.1 \mathrm{M}$ phosphate buffer) [30] for 2 days. (Decapitation was chosen because of the blood collection; based on our fast processing of dissection and fixation, the immunoreactivity is equivalent to perfusion.) After fixation, the brains were submerged

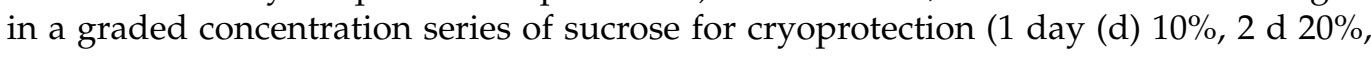
$2 \mathrm{~d} \mathrm{30 \%} \mathrm{in} 0.1 \mathrm{M}$ phosphate buffer). Following sucrose infiltration, the tissue was quickly frozen and serial coronal cryostat sections $(20 \mu \mathrm{m})$ were mounted on double-gelatinized glass slides.

\subsection{Immunohistochemistry}

Sections were processed by immunohistochemistry using the biotin-avidin peroxidase technique (VECTASTAIN Elite ABC, Vectorlabs, Burlingame, CA, USA) and 3.3'diaminobenzidine $(\mathrm{DAB})$ visualization as described $[31,32]$ with various anti-sera (Table 1). Thereby, not all analyses were performed for all experimental groups, depending on the availability of sufficient numbers of brain slices and antibody volumes. In such cases, respective parameters were assessed only for the experimental groups for which sufficient sample materials were available. 
Table 1. List of antisera used for immunostaining. 5-HT = serotonin (5-hydroxy-tryptamin), $\mathrm{AR}=$ androgen receptor, $\mathrm{AVP}=$ arginine-vasopressin, $\mathrm{Cry}=$ cryptochrome, $\mathrm{DBH}=$ dopamine beta-hydroxylase (the guiding enzyme of norepinephrine synthesis), GAD-65/67 = glutamic acid decarboxylase (the guiding enzyme of GABA synthesis), GRP = gastrin-releasing peptide, ME = met-enkephalin, NPY = neuropeptide $\mathrm{Y}, \mathrm{OR}=$ estrogen receptor, $\mathrm{OXY}=$ oxytocin, $\mathrm{PER}=\mathrm{Period}, \mathrm{SOM}=$ somatostatin, $\mathrm{SP}=$ substance $\mathrm{P}, \mathrm{TH}=$ tyrosine hydroxylase (the guiding enzyme of dopamine synthesis), VIP = vasoactive intestinal polypeptide.

\begin{tabular}{lll}
\hline \multicolumn{1}{c}{ Antibody against } & Working Dilution & \multicolumn{1}{c}{ Producer } \\
\hline AVP & $1: 1000$ & Own production [29] \\
VIP & $1: 1000$ & Sigma product, product number: V3508 \\
GRP & $1: 500$ & Affinity Res. Prod., Exeter, UK \\
GAD-65/67 & $1: 1000$ & Biotrend Chemikalien GmbH, Köln, Germany \\
5-HT & $1: 1000$ & Diasorin, Stillwater, MN, USA \\
SP & $1: 1000$ & Chemicon International, Temecula, CA, USA \\
NPY & $1: 1000$ & Affinity Res. Prod., Exeter, UK \\
ME & $1: 1000$ & Chemicon International, Temecula, CA, USA \\
OXY & $1: 1000$ & Own production [32] \\
SOM & $1: 1000$ & Chemicon International, Temecula, CA, USA \\
AR & $1: 50$ & Novocastra Laboratories, Newcastle, UK \\
OR & $1: 50$ & Novocastra Laboratories, Newcastle, UK \\
TH & $1: 1000$ & Chemicon International, Temecula, CA, USA \\
DBH & $1: 1000$ & Chemicon International, Temecula, CA, USA \\
Clock & $1: 60$ & Santa Cruz Biotechnology, Inc., Dallas, TX, USA \\
Per 1 & $1: 60$ & Santa Cruz Biotechnology, Inc., Dallas, TX, USA \\
Per 2 & $1: 60$ & Alpha Diagnostics Ltd., Reinach, Switzerland \\
Cry 2 & $1: 60$ & Alpha Diagnostics Ltd., Reinach, Switzerland \\
\hline
\end{tabular}

The antibodies used for the immunohistochemical analyses were assessed for specificity in our laboratories of the Institute of Anatomy of the University of Frankfurt/Main, Germany. In particular, cross-reactivity to related peptide sequences was excluded, antibodies after preincubation with specific antigen did not stain, and replacement of individual reaction steps by buffers prevented immunostaining.

The semiquantitative analysis of the immunostained sections was based on planimetric methods as previously described for the SCN $[29,31]$. In all other nuclei, the assessed areas were placed within the core of the various nuclei without crossing their boundaries. The area of the specifically stained structures (perikarya and fibers) was calculated as percent of the representative sample area of the brain nucleus (mean values). The outlines of the three brain nuclei studied could be easily recognized by their specific immunohistochemical staining patterns and by their cytoarchitecture as verified by microscopic observation applying the Nomarski technique (Zeiss Axioplan, Oberkochen, Germany).

The microscope (Fotomicroscope III, Zeiss, Göttingen, Germany) was connected to the computer via a video camera and an A/D image converter. In order to have reproducible illumination conditions at the microscope, the Köhler illumination principle, a $10 \times$ photo eyepiece, the $1.25 \times$ "optoview" setting and the objectives $25 \times$ (plan 25/0.45; 160/0.17; Carl Zeiss 5130955; Göttingen, Germany) and 40× (plan 40/0.65; 160/0.17; Zeiss West Germany 460710-9904; Göttingen, Germany) were used. All internal filters were removed and the field diaphragm was set to the field of view size. In this way, and due to a lamp voltage setting that was the same for all analysis sessions, reproducible illumination was ensured. For better contrast of the diaminobenzidine staining, an illumination wavelength of $520 \mathrm{~nm}$ (green light) was set on an interference gradient filter.

The following evaluations were made with the $25 \times$ objective: AVP, VIP, GRP, GAD65/ 67, NPY, OXY in the SON and PVN, AR in the PVN, OR in the PVN, TH, DBH, 5-HT in the dorsalis raphe nuclei. The following evaluations were made with the $40 \times$ objective: SP, ME, SOM, AR in the medial pre-optic area as well as in the medial periventricular nucleus and OR in the medial preoptic area. Depending on the selected objective and the resulting size of the sample area, different relative proportions of the stained area resulted. For example, 
a stained fiber or a stained perikaryon represented a larger area relative to the sample area when using the $40 \times$ objective than using the $25 \times$ objective.

Using the computer-assisted image analysis system VIDAS (Vidas $2.1^{\circledR}$; Kontron, Eiching, Germany), a representative rectangular area of constant size was selected within each stained nuclear area. Within this reference area, the total area of immunostained cells and fibers was measured and expressed as a percentage of the sample area. Thereby, six serial sections in $100 \mu \mathrm{m}$ distances per nucleus were used for evaluation, showing comparable sections of the respective nuclear area. The threshold of positive immunostaining was determined using a densitometric paradigm: After computer contrast enhancement, the absorbance of specific immunostaining was interactively selected. Non-specific artifact staining was interactively deleted and thus not recorded.

The photographic documentation was carried out on a microscope "axioscope" (Zeiss, Göttingen, Germany) attached with a digital camera. Representative sections that had previously been evaluated with the VIDAS $2.1^{\circledR}$ (Kontron, Eiching, Germany)-supported analysis technique were selected for documentation. The digitized images were processed with the Axio Vision 3.1 ${ }^{\circledR}$ program from Carl Zeiss Vision GmbH (Zeiss, Göttingen, Germany).

Due to excessive background staining, the serotonergic immunoreactivity in the fibers in the area of the suprachiasmatic nucleus could not be evaluated on the computer. Therefore, since only serotonin-containing nerve fibers but no serotonin-containing perikarya occur in the SCN $[33,34]$, a camera-lucida technique $[35,36]$ was used. For this purpose, the serotonergic fibers in the ventromedial part of the suprachiasmatic nucleus were visualized in representative sections at $400 \times$ magnification under the microscope. Using deflection prisms (drawing tube for "Axioplan" microscopes, Zeiss, Göttingen, Germany), the image was projected onto a white sheet of standard DIN A4 copy paper, where the fiber courses were traced using a black fiber pen (Stabilo ${ }^{\circledR}$-True Marker, STABILO International Gmbh, Heroldsberg, Germany) with a minimum diameter of $0.4 \mathrm{~mm}$. Again, six drawings were made per nucleus. The sheets were scanned with a "Network HighScan professional ${ }^{\circledR 1}$ (MediaMarkt, Ingolstadt, Germany) scanner in greyscale at $72 \mathrm{dpi}$ (dots per inch) and saved as "bmp" formats with $567 \times 796$ pixels each. The number of black pixels was calculated and indicated for each image using the program Adope Photoshop 7.0 ${ }^{\circledR}$ (Adope Systems Engineering, Hamburg, Germany).

\subsection{Blood Analyses}

Blood levels of arginine-vasopressin and testosterone were analyzed by use of radioimmunoassay (AVP, Vasopression RIA RK-AR1, Bühlmann Laboratories, Schönenbuch, Switzerland) or chemiluminescence-immunoassay (testosterone, Advia Centaur Testosteron Test, Advia Centaur, Bayer Corporation, Leverkusen, Germany) techniques as commissioned work by Biocontrol (Ingelheim, Germany).

\subsection{Statistics}

Statistical assessment was based upon many neurobiological sections of few individuals. About six sections per animal, i.e., 12 sections of bilaterally located nuclei, in five animals $=60$ samples per experimental group were analyzed, while the number of assessed animals was kept small for ethical reasons. The anterior-posterior distance between each section was $100 \mu \mathrm{m}$. Mean values of the results of those serial sections were included in the assessments. However, due to the low number of animals per experimental group, only non-parametric methods were applied, i.e., Whitney-Mann U testing if only two experimental groups were compared and Kruskal-Wallis testing as well as subsequent post-hoc testing with Dunn-Bonferroni tests in case of more than two experimental groups. Statistical assessments were performed applying the software GraphPad Instat version 3.06 (GraphPad Software Inc., San Diego, CA, USA). Significance was accepted at $p<0.05$. 


\section{Results}

\subsection{Behavioral Changes}

The observations during the pre-tests verified that the diurnal sleep phase started at the end of the dark period shortly before ZT 00:00. This main diurnal sleep phase continued for 4-6 h, obvious arousal reactions were not observed. Accordingly, the pretests on the comparison of undisturbed sleep with short-term manual sleep deprivation for $6 \mathrm{~h}$ and intermediate-term manual sleep deprivation for $20 \mathrm{~h}$ were timed to end at ZT 05.00.

The pretests on sexual stimulation with exposition to pheromone and female hamsters led to a tremendous increase in physical activity and arousal of the male hamsters at ZT 00:00 when the animals usually started sleeping. Until ZT 01:30, the hamsters intensively tried to cross the barrier to contact the females. At ZT 02:00, two males fell asleep, at ZT 02:30 only one male still tried to cross the barrier, at ZT 3:30 all-male hamsters were sleeping. Similar, slightly less pronounced activity was observed in the pheromone-only group.

According to the observed time span of maximum courtship behavior, the sacrifice of the groups of hamsters for the comparison of sleep deprivation due to manual handling, sexual stimulation by pheromones and females, pheromone stimulation-only and immobilization stress was set at $60 \mathrm{~min}$ after the start of the experiment. Therefore, the animals were sacrificed at ZT 01.00. The immobilized group showed high levels of alertness during all $60 \mathrm{~min}$ of immobilization, tried to perform escape maneuvers and to bite until decapitation after the same interval. The hamsters that were deprived of sleep by gentle manual handling showed signs of tiredness such as attempts of achieving curled-up sleeping positions until decapitation.

\subsection{Changes of Immunoreactivity to Neuromessengers, Time Keeping Proteins and Steroid Receptors in Cerebral Entities as Well as Their Concentrations in Blood}

An overview of the assessed cerebral entities is provided in Figure 1. Immunoreactivity to antisera against arginine-vasopressin (AVP), vasoactive intestinal polypeptide (VIP), gastrin-releasing peptide (GRP) and GAD-65/67 was detected in perikarya and fibers of the suprachiasmatic nucleus (SCN) of golden hamsters while there was immunoreactivity to substance P (SP), serotonin (5-HT), met-enkephalin (ME), and neuropeptide $\mathrm{Y}(\mathrm{NP}-\mathrm{Y})$ in fibers only.

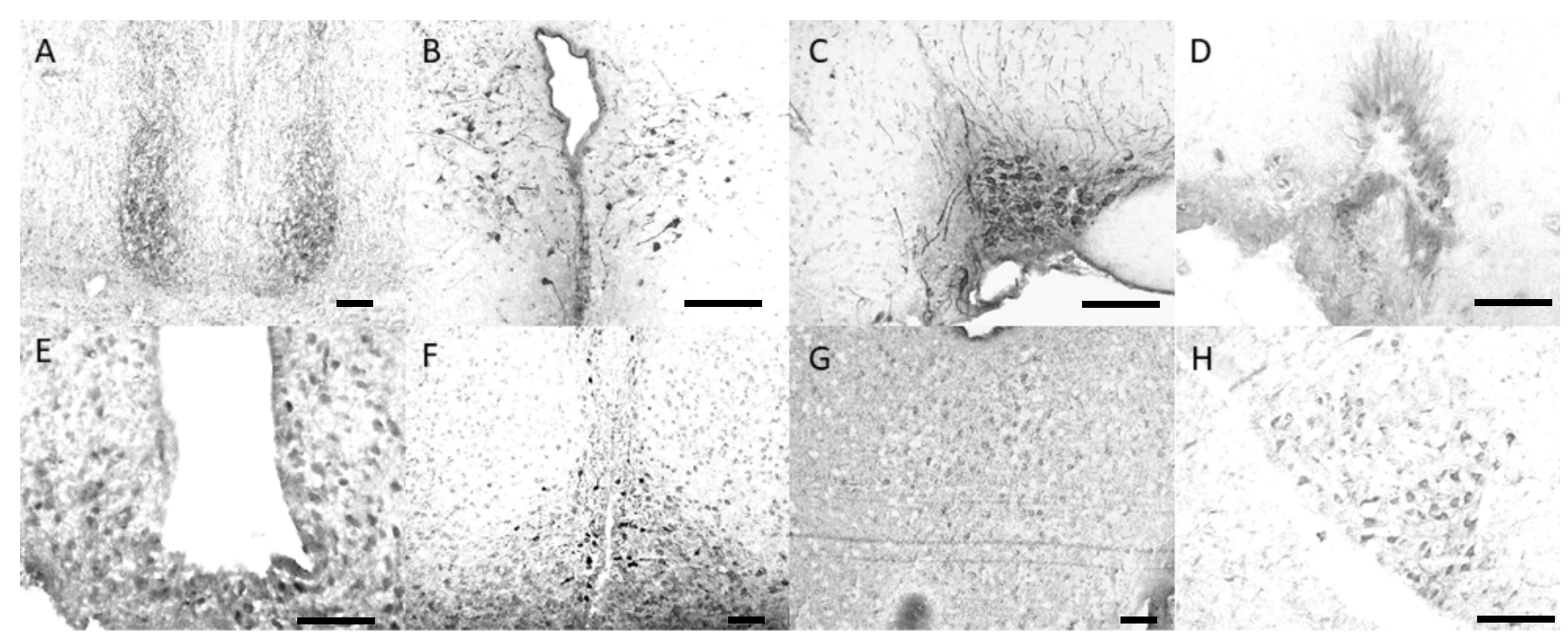

Figure 1. Example microphotographs of cerebral entities of male Syrian hamsters analyzed in the present investigation. (A) suprachiasmatic nucleus (anti-gastrin releasing peptide staining), (B) paraventricular nucleus (anti-arginine-vasopressin staining), (C) supraoptic nucleus (anti-arginine vasopressin staining), (D) medial preoptic area (anti-androgen receptor staining), (E) medial periventricular nucleus (anti-somatostatin staining), (F) infundibular nucleus (anti-tyrosine hydroxylase staining), (G) dorsal raphe nucleus (anti-serotonin staining), (H) A7 neuron population (anti-dopamine beta-hydroxylase staining). Scale bar $100 \mu \mathrm{m}$. 
Both short-term manual sleep deprivation settings, i.e., sleep deprivation for $6 \mathrm{~h}$ with assessment at ZT 05.00 (group 3b) and sleep deprivation for $1 \mathrm{~h}$ with assessment at ZT 01.00 (group 3a), did not show significantly different results with the exception of higher oxytocin (OXY) immunoreactivity in the paraventricular nucleus (PVN) in the 1-h sleep deprivation group. For all other comparably assessed entities, there was no difference between the two short-term sleep deprivation groups.

Lower OXY levels in the PVN compared to the 1-h manual sleep deprivation group (group 3a) were also seen in the sleeping animals (group 5). In the supraoptic nucleus (SON), in contrast, lower OXY levels were observed in group 2 (pheromone stimulation only) as compared to both the 1-h sleep deprivation group (group $3 a$ ) and the sexualstimulation group 1, respectively.

A highly differentiated pattern was seen for AVP in the different assessed hypothalamic entities as well as in blood. In the SCN, increased AVP immunoreactivity was observed in the 1-h manual sleep deprivation group (group 3a) compared to the sleeping control animals (group 5) as well as to the animals exposed to sexual stimulation (group 1) and immobilization stress (group 4). In the PVN, in contrast, AVP levels of sexually stimulated hamsters (group 1) were increased compared to sleeping controls. In the SON, immobilization stress led to reduced AVP immunoreactivity compared to all three manual handling-induced sleep deprivation settings (group 3), while only the 1-h manual sleep deprivation group 3a showed significantly higher AVP levels compared to group 2 (pheromone only), too. In blood, in contrast, 5-HT was significantly increased in the pheromone-only group 2 compared to the 1-h manual sleep deprivation group $3 a$.

A decrease in the time-keeping proteins Clock and Period (Per) 2 in the SCN of sleeping animals compared to animals deprived of sleep for $20 \mathrm{~h}$ (group 3c) was observed, while such changes were undetectable for Per 1 and cryptochrome (Cry) 2 in the SCN.

In the PVN, immunoreactivity of androgen receptors (AR) and estrogen receptors (OR) were decreased in the sexually stimulated group 1 compared to the 1 -h manual sleep deprivation group 3a. In the medial preoptic nucleus (MPOA), in contrast, this decrease was not observable. Although Kruskal-Wallis testing suggested the significance of an overall difference between the groups assessed for AR in the MPOA, the post-hoc analyses indicated no further significance for the comparisons of the different experimental groups.

A similar pattern of reduced immunoreactivity in sexually stimulated hamsters (group 1) compared to hamsters deprived of sleep by gentle handling for $1 \mathrm{~h}$ (group 3a) was also observed for somatostatin (SOM) in the medial periventricular nucleus (MPVN).

Focusing on tyrosine-hydroxylase (TH), the guiding enzyme of dopamine synthesis, in the infundibular nucleus (IN), sleeping animals (group 5) showed lower immunoreactivity compared to animals manually deprived of sleep for $1 \mathrm{~h}$ (group 3a) and sexually stimulated animals (group 1), respectively, while only sexually stimulated hamsters (group 1) showed more TH compared to immobilized hamsters (group 4) as well. In sleeping hamsters (group 5), dopamine beta-hydroxylase (DBH), the guiding enzyme of epinephrine synthesis, was also decreased in the A7 neuron population of the brainstem compared to the sexual stimulation group 1 and the 20-h manual sleep deprivation group 3c.

Both sexual arousal, achieved by combining pheromone with contact to females (group 1), and short-term manual sleep deprivation for $6 \mathrm{~h}$ (group $3 \mathrm{~b}$ ) were associated with elevated levels of testosterone in blood compared to immobilization stress (group 4). Details of the above-mentioned facts are summarized in Table 2.

As shown in Table 3, short-term manual sleep deprivation for $1 \mathrm{~h}$ (group 1) led to an increase in the reactivity of most of the assessed messenger systems, while nearly uniform decreases were observed for sleeping (group 5) and immobilized (group 4) hamsters. In contrast, both prolonged sleep deprivation as well as stimulation either by pheromone alone (group 2) or by pheromone and females (group 1) led to a more differentiated response. Thereby, however, it was obvious that the addition of females to sole pheromone stimulation led to a reaction pattern considerably different than in the case of pheromone application alone. 


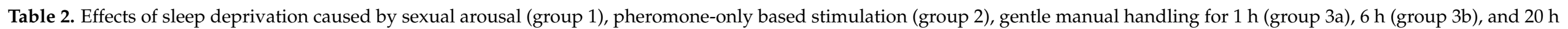

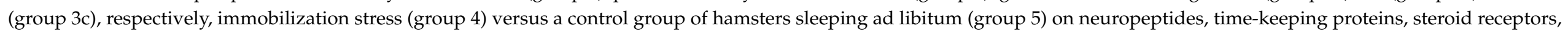

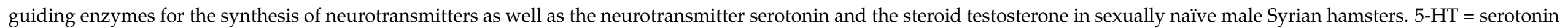

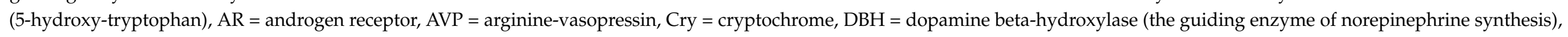

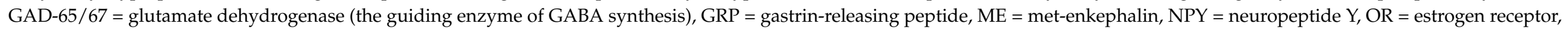

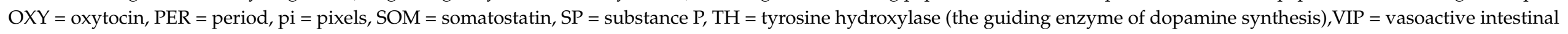

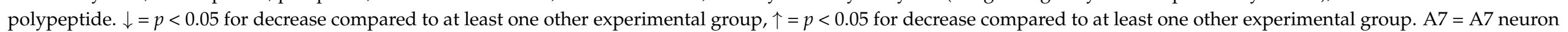

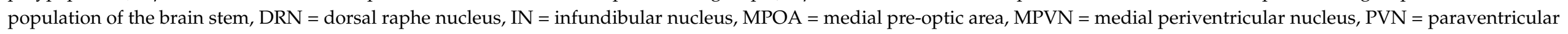
nucleus, $\mathrm{SCN}=$ suprachiasmatic nucleus, $\mathrm{SON}=$ supraoptic nucleus. $\mathrm{ZT}=$ zeitgeber time. - = data missing. Data are provided as mean values \pm standard deviation.

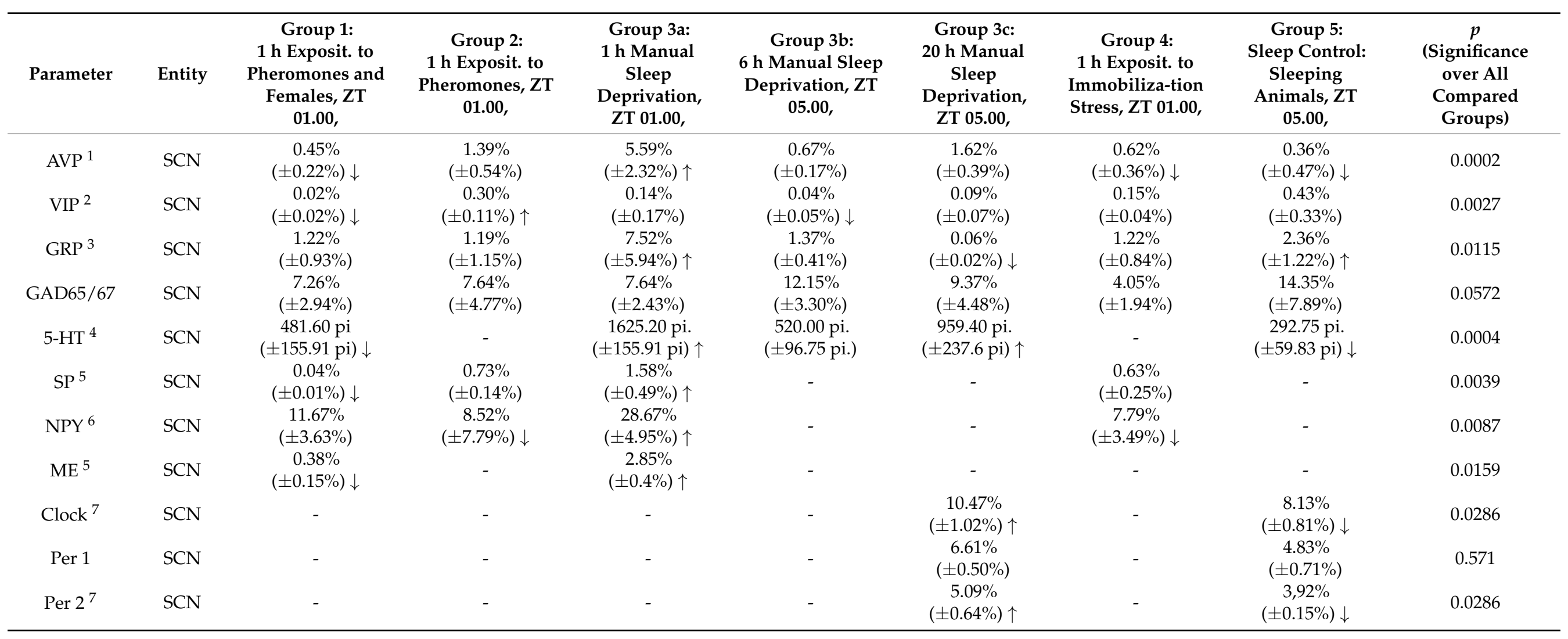


Table 2. Cont.

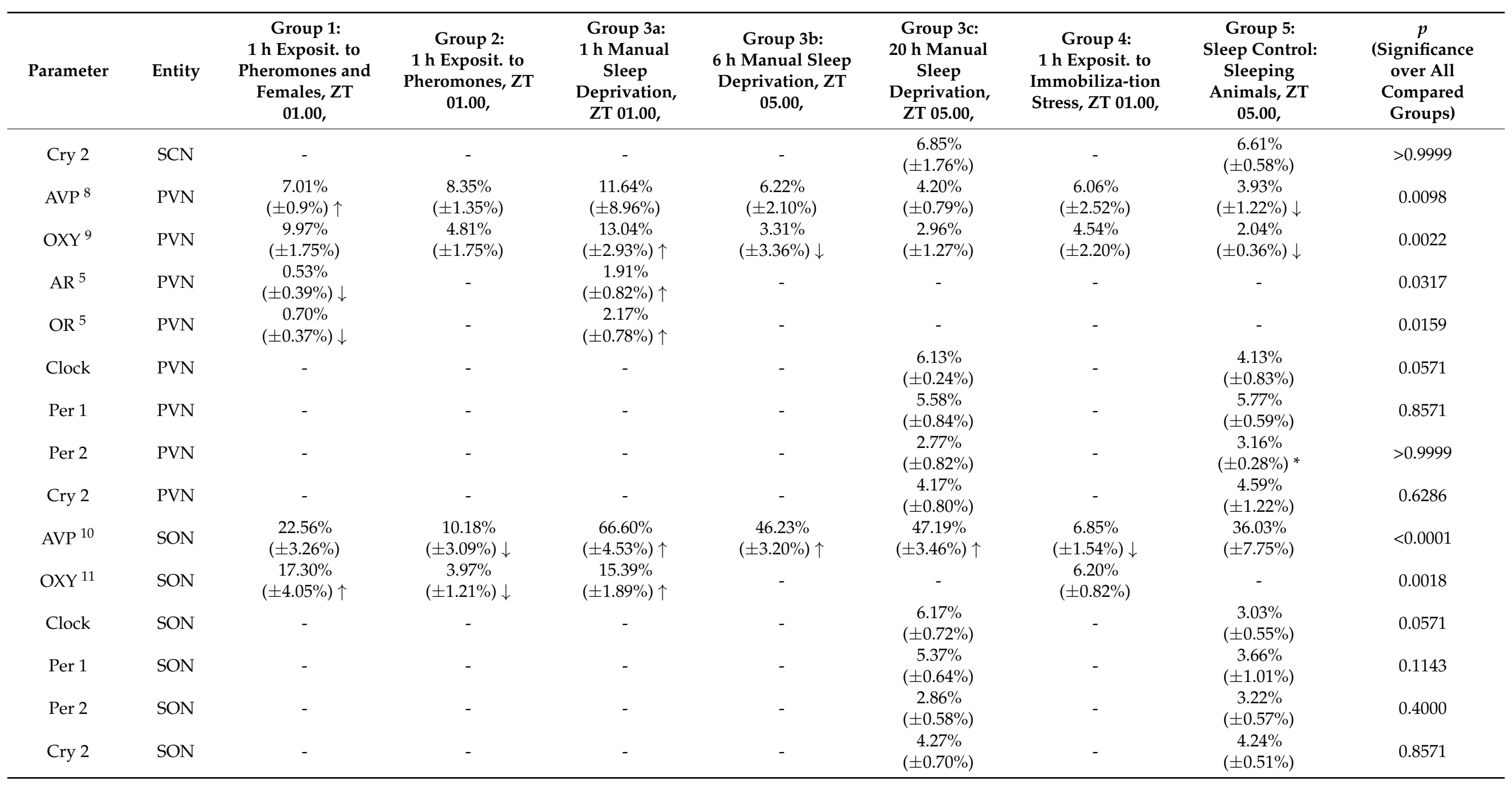


Table 2. Cont.

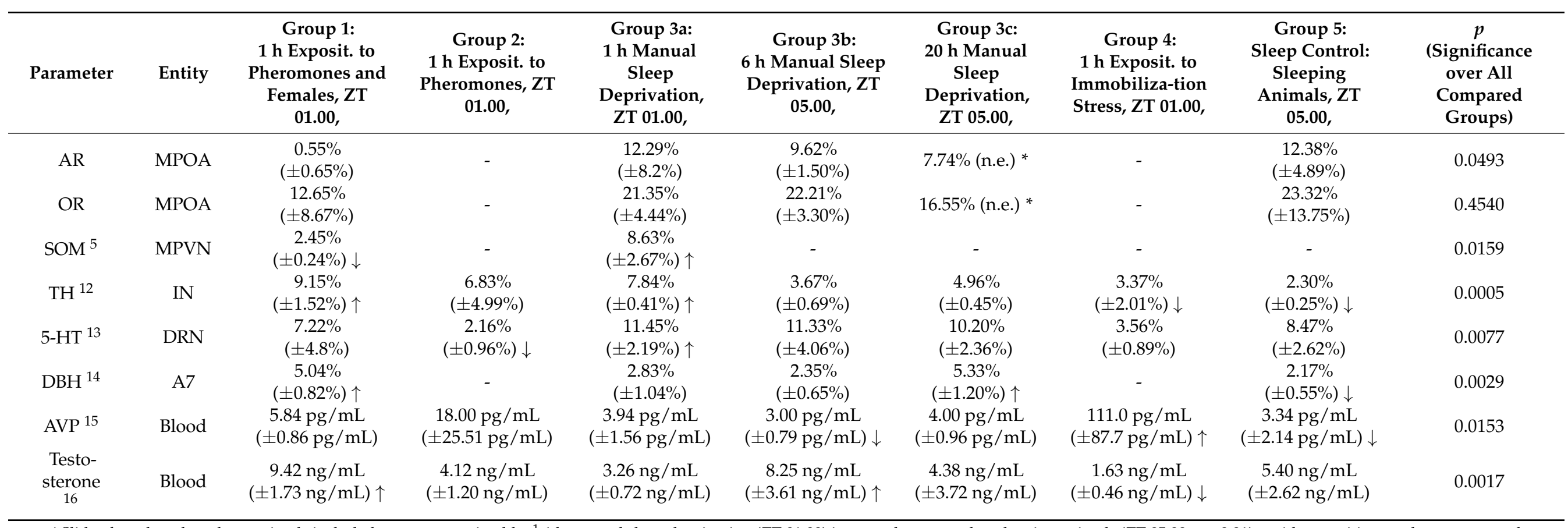

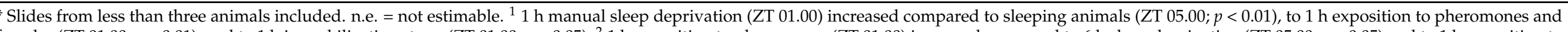

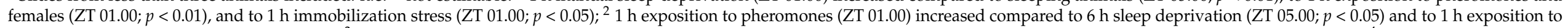

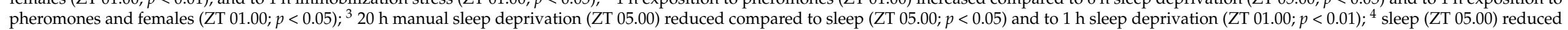

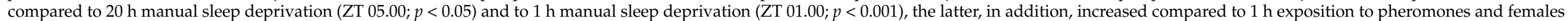

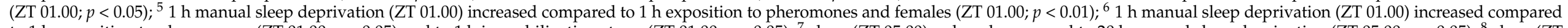

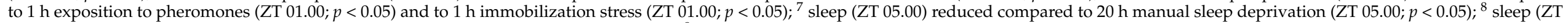

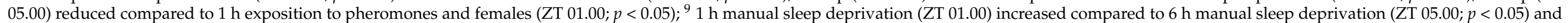

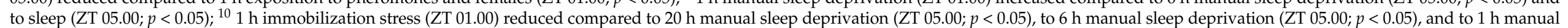

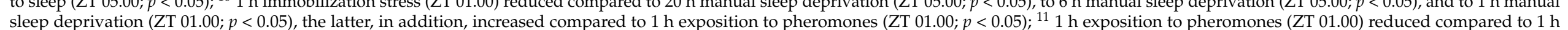

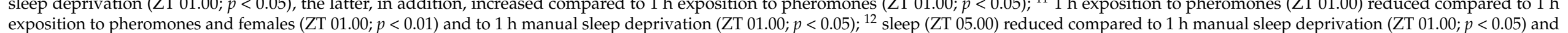

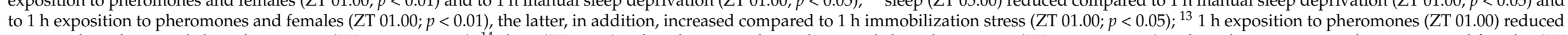

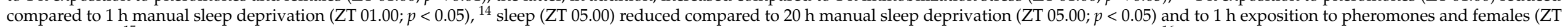

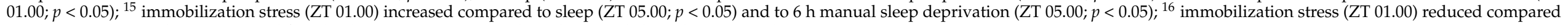
to $1 \mathrm{~h}$ exposition to pheromones and females (ZT 01.00; $p<0.01$ ) and to $6 \mathrm{~h}$ manual sleep deprivation (ZT 05.00; $p<0.01$ ). 
Table 3. Neuromessengers with relative increase or decrease compared to at least one other experimental group for different entities. 5-HT = serotonin (5-hydroxy-tryptophan), $\mathrm{AR}=$ androgen receptor, $\mathrm{AVP}=$ arginine-vasopressin, $\mathrm{DBH}=\mathrm{dopamine}$ beta-hydroxylase (the guiding enzyme of norepinephrine synthesis), GRP = gastrin-releasing peptide, ME = met-enkephalin, $\mathrm{NP}-\mathrm{Y}=$ neuropeptide $\mathrm{Y}, \mathrm{OR}=$ estrogen receptor, $\mathrm{OXY}=$ oxytocin, $\mathrm{PER}=$ Period, $\mathrm{SOM}=$ somatostatin, $\mathrm{SP}=$ substance $\mathrm{P}, \mathrm{TH}=$ tyrosine hydroxylase (the guiding enzyme of dopamine synthesis), VIP = vasoactive intestinal polypeptide. A7 = A7 neuron population of the brain stem, DRN = dorsal raphe nucleus, IN = infundibular nucleus, MPVN = medial periventricular nucleus, $\mathrm{PVN}=$ paraventricular nucleus, $\mathrm{SCN}=$ suprachiasmatic nucleus, $\mathrm{SON}=$ supraoptic nucleus. $\mathrm{ZT}=$ zeitgeber time.

\begin{tabular}{|c|c|c|c|}
\hline Experimental Group & $\begin{array}{l}\text { Sacrifice Time } \\
\text { (ZT) }\end{array}$ & $\begin{array}{l}\text { Relative Increase Compared to at } \\
\text { Least One Other Group }\end{array}$ & $\begin{array}{l}\text { Relative Decrease Compared to at } \\
\text { Least One Other Group }\end{array}$ \\
\hline $\begin{array}{l}\text { Intermediate-term sleep } \\
\text { deprivation }(20 \mathrm{~h})\end{array}$ & 05.00 & $\begin{array}{ll}\text { - } & \text { SCN: 5-HT, Clock, Per } 2 \\
\text { - } & \text { SON: AVP } \\
\text { - } & \text { A7: DBH }\end{array}$ & - $\quad$ SCN: GRP \\
\hline $\begin{array}{l}\text { Short-term sleep } \\
\text { deprivation }(6 \mathrm{~h})\end{array}$ & 05.00 & $\begin{array}{ll}\text { - } & \text { SON: AVP } \\
\text { - } & \text { Blood: testosterone }\end{array}$ & $\begin{array}{ll}\text { - } & \text { SCN: VIP } \\
\text { - } & \text { PVN: OXY } \\
\text { - } & \text { Blood: AVP }\end{array}$ \\
\hline $\begin{array}{l}\text { Short-term sleep } \\
\text { deprivation }(1 \mathrm{~h})\end{array}$ & 01.00 & $\begin{array}{ll}\text { - } & \text { SCN: AVP, GRP, 5-HT, SP, } \\
& \text { NP-Y, ME } \\
\text { - } & \text { PVN: OXY, AR, OR } \\
\text { - } & \text { SON: AVP, OXY } \\
\text { - } & \text { MPVN: SOM } \\
\text { - } & \text { IN: TH } \\
\text { - } & \text { DRN: 5-HT } \\
\end{array}$ & \\
\hline Sleep & 05.00 & - $\quad$ SCN: GRP & $\begin{array}{ll}\text { - } & \text { SCN: AVP, 5'-HT, Clock, Per } 2 \\
\text { - } & \text { PVN: AVP, OXY } \\
\text { - } & \text { IN: TH } \\
\text { - } & \text { A7: DBH } \\
\text { - } & \text { blood: AVP }\end{array}$ \\
\hline $\begin{array}{l}\text { Exposure to pheromone } \\
(1 \mathrm{~h})\end{array}$ & 01.00 & - $\quad$ SCN: VIP & $\begin{array}{ll} & \text { SCN: NP-Y } \\
\text { - } & \text { SON: AVP, OXY } \\
\text { - } & \text { DRN: 5-HT } \\
\end{array}$ \\
\hline $\begin{array}{l}\text { Exposure to pheromone } \\
\text { and females }(1 \mathrm{~h})\end{array}$ & 01.00 & $\begin{array}{ll}\text { - } & \text { PVN: AVP } \\
\text { - } & \text { SON: OXY } \\
\text { - } & \text { IN: TH } \\
\text { - } & \text { A7: DBH } \\
\text { - } & \text { Blood: testosterone }\end{array}$ & $\begin{array}{ll}\text { - } & \text { SCN: AVP, VIP, 5-HT, SP, ME } \\
\text { - } & \text { PVN: AR, OR } \\
\text { - } & \text { MPVN: SOM }\end{array}$ \\
\hline Immobilization stress $(1 \mathrm{~h})$ & 01.00 & - $\quad$ Blood: AVP & $\begin{array}{ll}\text { - } & \text { SCN: AVP, NP-Y } \\
\text { - } & \text { SON: AVP } \\
\text { - } & \text { IN: TH } \\
\text { - } & \text { Blood: testosterone }\end{array}$ \\
\hline
\end{tabular}

In addition to the example pictures shown above in Figure 1, we provide 15 appendix Figures A1-A15 in the Appendix A which show micrographs specifically demonstrating the significant differences in the immunoreactivity as summarized in Table 2 above. In detail, those figures are composed of micrographs showing the immunoreactivity to particular neuromessengers in specific brain nuclei. Thereby, only images were selected which demonstrate significant differences in the immunoreactivity as summarized in Table 2 above.

\section{Discussion}

The study was intended to analyze specific effects of sexual arousal on neurotransmitter and neuropeptide systems as well as the time-keeping protein patterns in the SCN, in its magnocellular target neurons in the PVN and SON as well as in other related cerebral entities of Syrian hamsters, next to hormone levels in the blood and sexual steroid respon- 
siveness as indicated by sexual steroid receptor density. To induce sexual arousal, the hamsters were stimulated with olfactory and optical cues during their main sleeping period. This type of stimulation was compared to sleep deprivation by mild manual handling and additionally compared to pheromone stimulation solely and to severe immobilization stress. Further, comparison with prolonged manual sleep deprivation and completed sleep periods was performed. The latter resulted in later zeitgeber time of sacrifice, however, we did not detect significant differences between scarification after terminating the sleep phase vs. that of hamsters after $1 \mathrm{~h}$ of sleep as described previously [29]. By mild manual handling, the (tamed) animals had to be repeatedly stimulated to prevent them from falling asleep for $1 \mathrm{~h}$ or longer during their main diurnal sleeping period, whereas severe stress caused high levels of alertness. As observed during the pre-tests, completely undisturbed golden hamsters could be woken up only by intense manual stimulation during this main sleeping period. The non-anthropogenic stimulation with species-specific pheromone, however, caused complete naturally based sleep deprivation with high levels of alertness, especially when supported by the presence of females. In line with these diversified behavioral effects, the reactivity pattern of the neurotransmitter and neuropeptide systems differed conspicuously among the three groups.

The behavioral changes of the assessed male hamsters as well as their markedly increased plasma testosterone levels suggest that the chosen experimental setting, i.e., the combination of an olfactory aphrodisin stimulation in the presence of females, was indeed suitable to induce sexual arousal. Steroids act largely permissive on male sexual behavior through interconnected limbic nuclei including the medial amygdala and the MPOA [4]. Indeed, the high concentration of blood testosterone associated with the sexual stimulation setting was associated with the down-regulation of sexual steroid receptors in the PVN, most likely decreasing steroid responsiveness, but not in the MPOA in this study. The sexual steroids' quantitative effect partially depends on co-circulating catecholamines in addition to the bioelectric state of testosterone binding cells of the limbic system [37]. Indeed, an increase in epinephrinergic brain stem activity was exemplarily demonstrated for the A7 neuron population as indicated by DBH levels in good concordance with this observation. Interestingly, however, intermediate-term sleep deprivation of about $20 \mathrm{~h}$ resulted in a similar increase. In total, a threefold increase in blood testosterone could be achieved by our sexual stimulation setting. In contrast, acute immobilization stress $[38,39]$ and chronic stress [40] are known to be associated with drastic and enduring decreases in plasma testosterone levels. In line with this, we observed reduced concentrations of blood testosterone due to immobilization stress for $1 \mathrm{~h}$ not only in comparison to sexual stimulation but even compared to short-term sleep deprivation about $6 \mathrm{~h}$. We conclude that the optical and olfactory challenge associated with the sexual stimulation setting led to a mode of arousal other than the aversive stress setting and that it might have been associated with increased sexual appetence. Considerably different immunoreactivity patterns resulting from pheromone stimulation alone might indicate that the visual contact to females may have been of importance for a sexual appetence-associated interpretation of the pheromone stimulus.

The occurrence of appetence behavior and the drastic increase in blood testosterone in the sexually stimulated animals as compared to immobilization stress and sleep deprivation for $6 \mathrm{~h}$ are most likely caused by differential alterations in the messenger systems of the circadian pacemaker in the SCN and its input regions as well as its output targets. The most prominent efferent projections from the SCN lead to the PVN [41], which is believed to play an important role in the regulation of sexual behavior [42]. The nonapeptide AVP expressed in both nuclei is suggested as a messenger of this axis. AVP is believed to facilitate sexual behavior $[43,44]$ with the medial amygdaloid nucleus and the hippocampus as prominent sites of behavioral control [43]. We observed decreases of immunoreactivity in the SCN compared to short-term manual sleep deprivation for $1 \mathrm{~h}$ associated with increased levels in the PVN compared to sleeping animals. Stress, particularly repeated stress, may increase AVP plasma levels due to activation of AVP synthesis in parvocellular 
corticotropin-releasing hormone-producing neurons of the PVN [45,46]. The AVP reaction pattern in the SCN due to acute immobilization stress was virtually identical to sexual stimulation, suggesting that this reaction may be conserved in rewarding and aversive arousal. However, immobilization stress also led to reduced AVP in SON compared to short-term manual sleep deprivation for $1 \mathrm{~h}$ as well as to increased AVP levels in blood compared to manual sleep deprivation for $6 \mathrm{~h}$ and $20 \mathrm{~h}$.

In sharp contrast to AVP, both VIP and GRP seemed to be more pronouncedly influenced by their previously described diurnal rhythmic release in SCN neurons [32] than by the mode of external stimuli. In the described experimental setting, VIP was slightly but significantly increased by pheromone stimulation alone compared to combined stimulation with pheromone and the abundance of females as well as to sleep deprivation for $6 \mathrm{~h}$ with ZT 05.00 for sacrifice. GRP was more pronouncedly influenced by the duration than by the mode of sleep deprivation, with $20 \mathrm{~h}$ leading to a significant decrease in immunoreactivity in SCN compared to short-term manual sleep deprivation of $1 \mathrm{~h}$ or sleep ad libitum. The observed increase in GRP in the SCN of sleeping hamsters matches previous results [29] and indeed, VIP is known to be more important for peripheral reactions during sexual arousal $[12,47,48]$, while the central nervous VIP release, e.g., in the hypothalamic median eminence, is known to be triggered by chronic but not by acute stress [49]. GRP seems to be more relevant for the type of sexual preferences in mice than for the sexual reaction itself [13]. Stress responses related to GRP were studied more extensively in the peripheral nervous system, e.g., depletions of GRP-containing vesicles in gastric nerve fibers caused by stress [50].

The neurotransmitter GABA is involved in neural processes inhibiting sexual activity at various central nervous sites [51,52], while GABA-antagonists facilitate mating behavior [53]. Partially, the negative GABA effect is influenced by olfactory stimuli [54]. However, prolonged but not acute stress is known to be associated with increased quantities of GABA in the hypothalamus of rats $[55,56]$. GAD-65/67 immunoreactivity in SCN neurons, however, was not affected by our sexual arousal setting, neither by the mode nor by the duration of sleep deprivation.

The general influence of intermediate-term manual sleep deprivation for $20 \mathrm{~h} \mathrm{com}$ pared to sleep on the immunoreactivity of the time-keeping proteins Clock, Per 1, Per 2 and Cry 2 [57-61] was recorded in SCN, PVN, in SON. Interestingly, an increase in Clock and Per 2 in SCN of the hamsters deprived of sleep compared to sleeping hamsters remained the only observed significant effects, most likely as compensatory phenomena as suggested before $[57,58]$. The increased Per 1 activity in the $20 \mathrm{~h}$ manual sleep deprivation group is well in line with the previously described Per 1 induction by serotonergic activity [62].

SP in the mesencephalic central grey can facilitate sexual activity in rats [63]. In afferent fibers to the SCN, SP immunoreactivity was drastically reduced after our sexual stimulation experiment. The SP reactivity to stress was reported to differ among various brain nuclei: decreased SP immunoreactivity was found in the septum, striatum and hippocampus of rats in response to acute stress [64], an increase in SP was observed in hypothalamic sites after exposure to prolonged stress for $24 \mathrm{~h}$ [65]. In spite of those previous observations on acute stress [64], no significant changes in afferent fibers projecting to the $\mathrm{SCN}$ were recorded due to immobilization stress for $1 \mathrm{~h}$.

NPY predominantly shows inhibitory effects on sexual behavior [66,67]. In rats, the NPY response to repeated aversive stress is diversified and depends on the exact mode of the stimuli applied [67-69]. In the experimental setting as presented here, NPY immunoreactivity in afferent fibers to the SCN was decreased after pheromone-only stimulation and after immobilization stress compared to manual sleep deprivation for $1 \mathrm{~h}$, while this phenomenon could not be significantly demonstrated for the sexual stimulation setting. At least with regard to this neurotransmitter, the solitary pheromone stimulation resulted in a reaction more similar to aversive stress than to sexual appetence.

Both ME and 5-HT are known to mediate inhibitory effects on sexual activity $[8,10]$ and were, accordingly, measured in lower quantities in afferent fibers to the SCN after 
sexual stimulation compared to manual sleep deprivation for $1 \mathrm{~h}$. The same applies to SOM immunoreactivity in PVNM neurons [9] which are known to project to the SCN [17]. In addition, in comparison to the sleeping animals, both intermediate-term manual sleep deprivation and short-term manual sleep deprivation were associated with increased 5-HT levels in afferent fibers in the SCN, a finding which is in line with previous results [70,71]. In the dorsal raphe nucleus, however, this change was not reproducible with decreased 5-HT immunoreactivity only after sole pheromone stimulation compared to manual sleep deprivation for $1 \mathrm{~h}$. Since the dorsal raphe nucleus is influenced by epinephrinergic afferences from the brain stem [20], DBH as the guiding enzyme for the neurotransmitter epinephrine was exemplarily assessed in the A7 neuron population of the brain stem. The differentiated $\mathrm{DBH}$ reaction pattern in the $\mathrm{A} 7$ neuron population with significantly decreased immunoreactivity in sleeping hamsters compared to hamsters exposed to prolongated manual sleep deprivation for $20 \mathrm{~h}$ as well as to sexually stimulated hamsters, however, were neither directly nor reciprocally reflected by the 5-HT immunoreactivity on DRN level, suggesting a stronger dominance by other influences. However, it may reflect the known stimulating effects of the brainstem epinephrine on arousal [21].

Dopamine is a widely accepted neurotransmitter facilitating sexual activity [5]. In line with this, higher levels of tyrosine hydroxylase $(\mathrm{TH})$, the guiding enzyme for dopamine synthesis, were measured in the infundibular nucleus (IN) of sexually stimulated animals compared to immobilized ones. Sleeping animals showed lower TH immunoreactivity compared to both sexually stimulated animals and animals deprived of sleep by gentle manual handling for a period of $1 \mathrm{~h}$ which is in good concordance with previous findings in other hypothalamic entities [72].

OXY widely facilitates acute sexual arousal [73-75], and, influenced by oxytocinergic neurons in the PVN, penile erections [76,77] and the orgasmic process [73,78]. The initial sexual encounter stimulates OXY secretion combined with the activation of synthesis in oxytocinergic neurons in hypothalamic nuclei [42]. However, our sexual arousal setting, similar to the $1 \mathrm{~h}$ manual sleep deprivation, showed only increased OXY levels in the SON compared to the group receiving pheromone stimulation solely, again suggesting different reactions due to pheromones alone compared to the combination of pheromones and females. No blood oxytocin was quantified, so it remains unknown whether the reaction in the sexually stimulated animals was due to low neuroendocrine secretion or due to a compensation of the secretion by intracellular de novo synthesis of OXY. Regarding OXY immunoreactivity in the PVN, there was even increased OXY immunoreactivity in hamsters manually deprived of sleep for $1 \mathrm{~h}$ as compared to this mode of sleep deprivation for $6 \mathrm{~h}$ and sleep ad libitum. On the other hand, the stimulation interval of $1 \mathrm{~h}$ might have been too short to detect alterations in the OXY synthesis and/or depletion from the magnocellular perikarya. In rats, acute exposure to immobilization stress was described to result in hypothalamic OXY synthesis and secretion mainly via the PVN [45] but not via the SON [79]. OXY immunoreactivity in both PVN and SON was, however, not significantly affected in our immobilization setting.

Increased testosterone blood levels suggested the achievement of the desired stimulating effect in our sexual stimulation group compared to the hamsters deprived of sleep by the aversive stimulus of immobilization stress [4]. The observed similar increase in the $6 \mathrm{~h}$ manual sleep deprivation group is an interesting phenomenon. In the PVN but not in the MPOA, compensatory down-regulation of sexual steroid receptors was observed in the sexually stimulated hamsters compared to the $1 \mathrm{~h}$ manual sleep deprivation group.

Since only one diagnostic method, i.e., semiquantitative immunohistochemistry, was applied for the quantification of each assessed parameter within the animals' brains, the study implies an undeniable limitation; the non-stoichiometric immunoreactions may cause intraassay variations which limit the validity of results with smaller levels of significance. Accordingly, weak significance has to be considered as preliminary and hypothesisforming in this way and future studies applying confirmatory methods, comprising, e.g., radioimmunoassays, quantitative Western blotting, high-pressure liquid chromatography 
(HPLC) or in situ hybridization targeting the messenger RNA of protein messengers, are highly desirable.

The fact that correction for multiple testing was not included in the statistical approach is another limitation of the study. Otherwise, a considerably higher number of animals would have been needed to show small differences in immunoreactivity. However, it cannot be excluded that some of the observed minor differences were in this way just by chance. This is another reason why some of the results should be considered as hypothesisforming only.

As another limitation of the study, we did not discriminate potential responders and non-responders towards sleep deprivation. If there were non-responders among the animals, the respective impact on the assessed neuromessengers will most likely have affected the standard deviations of the measured results and contributed to partly weak significances for the recorded effects. However, since the Syrian hamsters used in our investigation were litter mates of an inbred lineage, this aspect should be of minor importance.

\section{Conclusions}

In the present investigation, different regimens of sleep deprivation were tested. All of them successfully prevent sleep during the main diurnal sleep phase. However, stressinduced and, somewhat surprisingly, pheromone-and-female-induced sleep prevention were much more effective than manual handling in the tamed golden hamsters. In line with this, the different neuromodulator systems displayed rather diversified reactivity patterns among the experimental groups. It is worthwhile to elucidate the potential neuronal mechanism, how the experimental settings might have affected the hypothalamic timing system responsible for the alterations in sleeping behavior.

Gentle manual handling in tamed animals may not be a strong waking signal; the animals are used to tactile stimuli which are perceived via fast adapting mechanoreceptors [80]. Sleep deprivation for more than $1 \mathrm{~h}$ was only possible by frequently repeated manual stimulations, and significant alterations in the neuromodulator systems of the hypothalamic timing control nuclei were not observed until $20 \mathrm{~h}$ of such permanent handling as compared to animals manually deprived of sleep for $6 \mathrm{~h}$ and animals that were allowed to sleep at libitum during their natural diurnal period of sleep.

Severe stress caused by our drastic type of immobilization directly affects the entire central nervous sympathetic control system including the amygdala via the locus coeruleus nuclei [81]. The latter is abundantly interconnected with the magnocellular hypothalamic nuclei, in particular with the PVN. The PVN is strongly interconnected with the SCN and, accordingly, influences the circadian clock and the timing system of sleep. The significant decrease in AVP and NPY after stress stimulation may be based on this input to the SCN. Furthermore, the PVN is the superior control entity for the sympathetic output via the neuronal (paravertebral sympathetic truncus) and humoral axis (AVP and ACTH) [82]. In line with these facts, we observed a decrease of AVP in the SON in the magnocellular system, resulting in an increase in blood. Unfortunately, the corticotropin-releasing factor(CRF-) reactivity was not analyzed, because CRF was found to stimulate the synthesis of the sleep inhibiting peptide orexin [83].

The architecture of the combined neuronal and humoral pathway conveying olfactory stimuli to the testosterone secreting Leydig cells includes the terminal nerve, the olfactory tubercles and the preoptic nuclei as neural components as well as GnRH (gonadotropin releasing hormone) and LH (luteinizing hormone) as humoral components [84]. The strong increase in testosterone in the blood of golden hamsters stimulated by pheromone in the abundance of females is mediated via this axis. The increased testosterone levels can directly act on androgen receptors in the SCN [85] or in the medial preoptic nucleus [86]. The latter is interconnected with the PVN as well as with the lateral septum and with the amygdala. In the PVN, even a compensatory down-regulation of sexual steroid receptors was observed in our study. The amygdala and the septum, which are involved in emotional (and possibly olfactory) control, are connected with the PVN, the SON, and the SCN [87]. 
By activation of this axis, the observed alterations of neuromessenger immunoreactivity in the assessed hypothalamic nuclei may have been mediated or at least affected.

Generally, several reactivity patterns of neuromodulators behave similarly when comparing stress, pheromone-stimulation and combined pheromone-and-female-based sexual stimulation in Syrian hamsters, i.e., AVP in the SCN comparing sexual stimulation and immobilization, NP-Y in the SCN as well as AVP in the SON comparing pheromone-only stimulation and immobilization. These concordant patterns may be necessary to alter the sleep control via the hypothalamic melanin-concentrating hormone $(\mathrm{MCH})$ and the orexin system which express strong sleep-promoting or sleep-preventing actions, respectively $[88,89]$. , mediated by the axis in the hypothalamus and to facilitate the peripheral activity shown during both stress and pheromone/sexual stimulation.

Author Contributions: Conceptualization, F.N. and H.F.; methodology, F.N. and H.F.; software, H.F.; validation, F.N. and H.F.; formal analysis, H.F.; investigation, H.F.; resources, F.N.; data curation, H.F..; writing-original draft preparation, C.K., H.F. and F.N.; writing—review and editing, C.K., H.F. and F.N.; visualization, H.F.; supervision, F.N.; project administration, F.N. All authors have read and agreed to the published version of the manuscript.

Funding: This research received no external funding.

Institutional Review Board Statement: Principles of laboratory animal care and specific national laws were followed in line with the German standards when the experiments were performed between 2003 and 2005. In detail, all experiments were in accordance with a protocol approved by the Policy on Ethics, as approved by the Society for Neuroscience, and was consistent with Federal guidelines and the European Communities Council Directive.

Informed Consent Statement: Not applicable.

Data Availability Statement: All relevant data are provided in the manuscript. Raw data can be provided upon reasonable request.

Acknowledgments: The authors are grateful to Privatdozent Hans-Jürgen Mägert and Michael Walden for the donation of the aphrodisin containing solution. They further thank Privatdozent Helmut Wicht for excellent support in image analysis.

Conflicts of Interest: The authors declare no conflict of interest. 


\section{Appendix A}
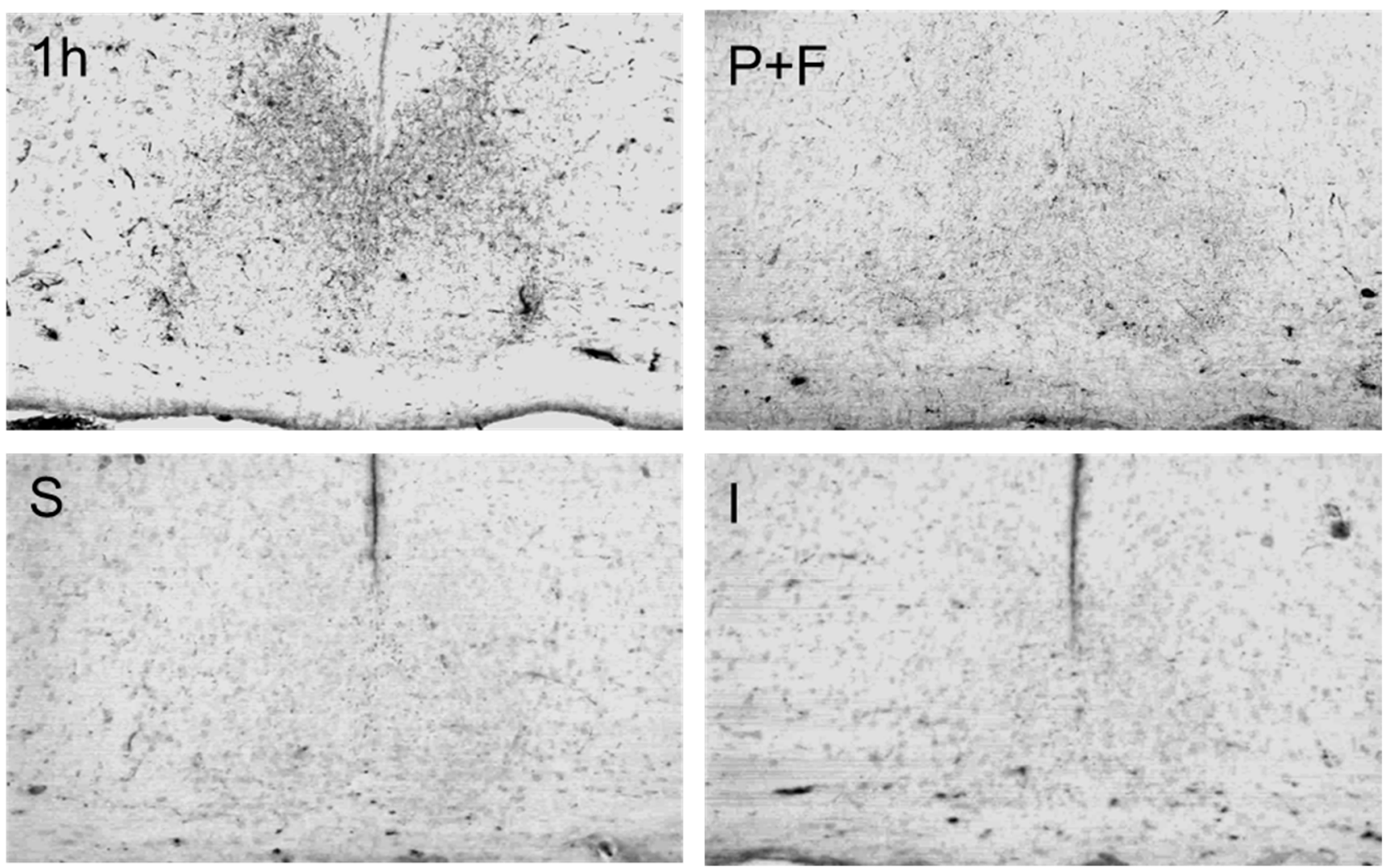

Figure A1. Arginine-vasopressin immunoreactivity in the suprachiasmatic nuclei of Syrian hamsters. Comparison between $1 \mathrm{~h}$ manual sleep deprivation (1 h, group 3a), sexual stimulation with pheromone and females ( $\mathrm{P}+\mathrm{F}$, group 1$)$, sleep ( , group 5) and immobilization stress (I, group 4). Magnification: $50 \times$.
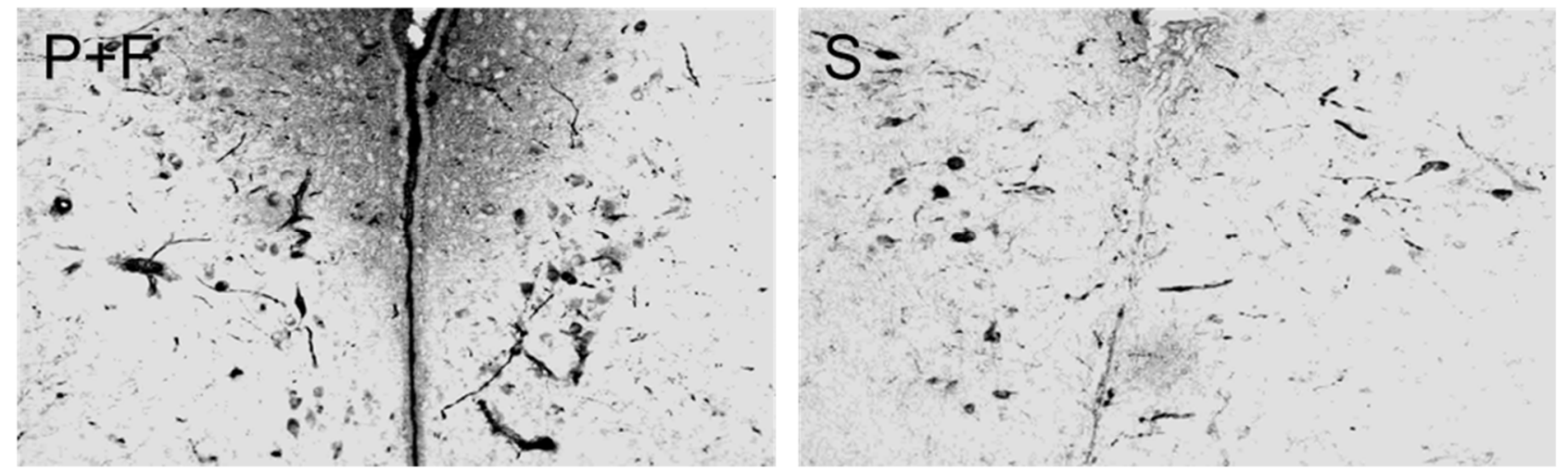

Figure A2. Arginine-vasopressin immunoreactivity in the paraventricular nuclei of Syrian hamsters. Comparison between sexual stimulation with pheromone and females $(\mathrm{P}+\mathrm{F}$, group 1$)$ and sleep (S, group 5). Magnification: $50 \times$. 

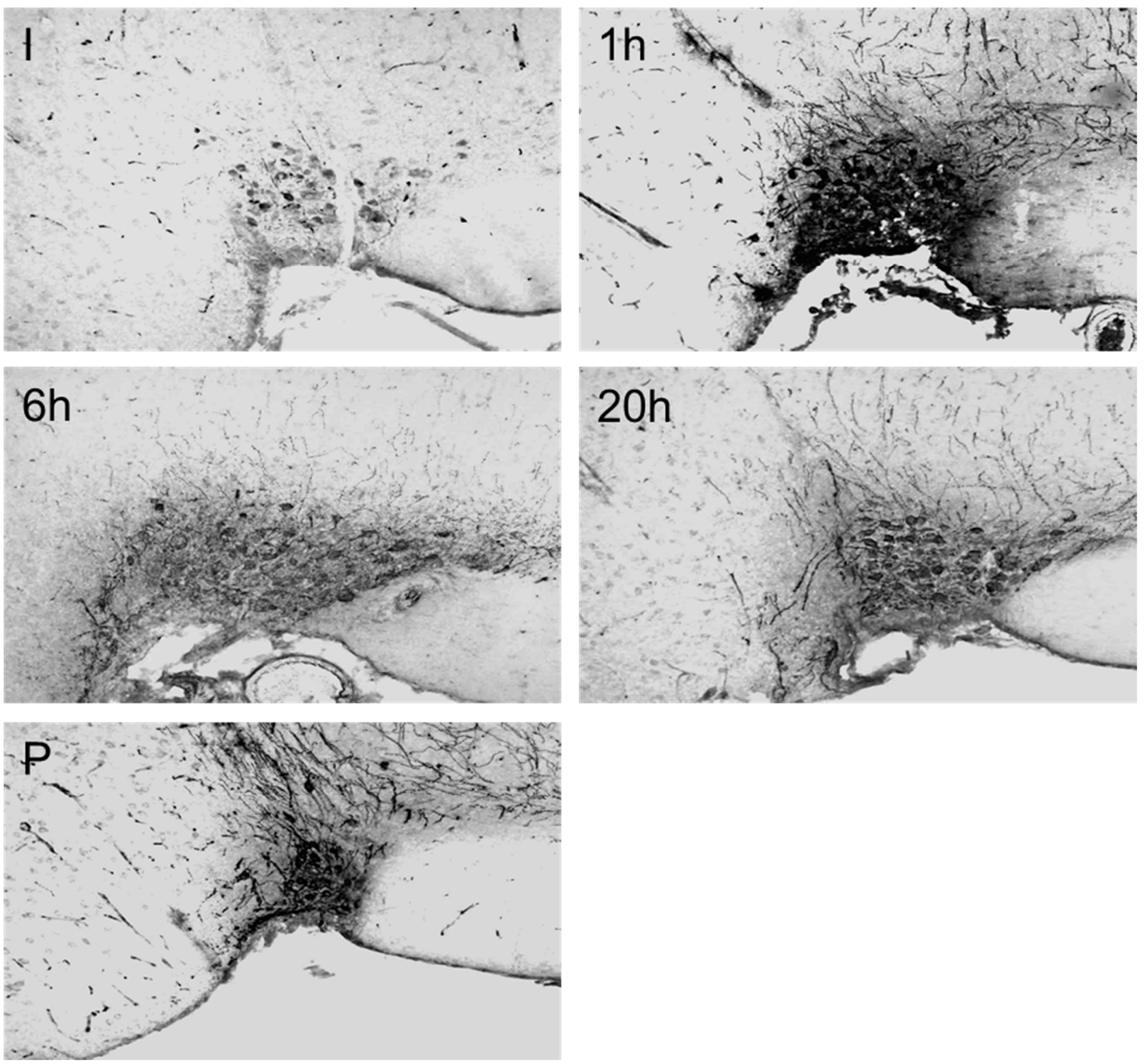

Figure A3. Arginine-vasopressin immunoreactivity in the supraoptic nucleus of Syrian hamsters. Comparison among immobilization stress (I, group 4), $1 \mathrm{~h}$ manual sleep deprivation ( $1 \mathrm{~h}$, group $3 \mathrm{a}), 6 \mathrm{~h}$ manual sleep deprivation (6 h, group 3b), $20 \mathrm{~h}$ manual sleep deprivation (20 h, group 3c) and sexual stimulation with pheromone (P, group 2). Magnification: $50 \times$. 

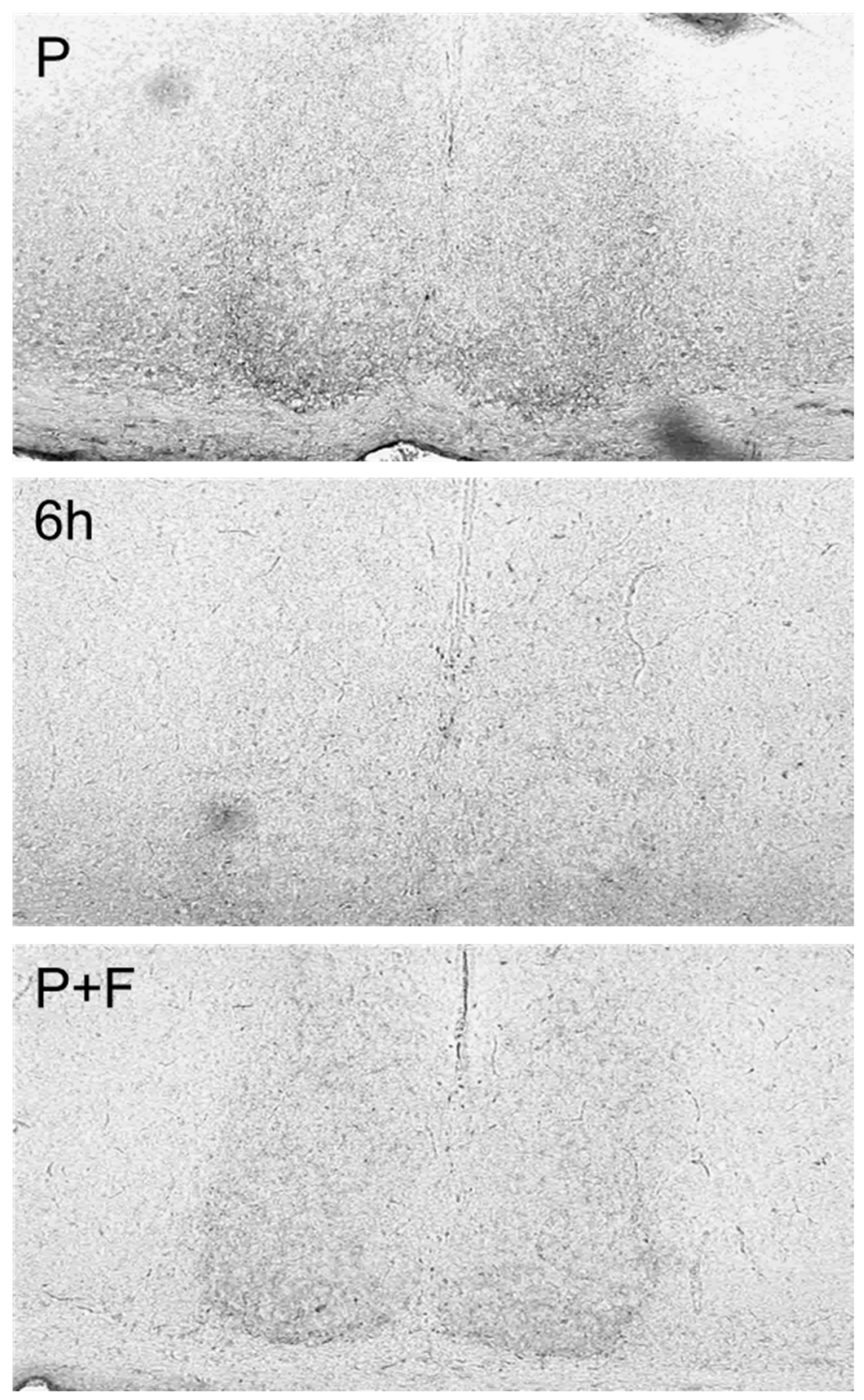

Figure A4. Vasoactive-intestinal peptide immunoreactivity in the suprachiasmatic nuclei of Syrian hamsters. Comparison between sexual stimulation with pheromone (P, group 2), $6 \mathrm{~h}$ manual sleep deprivation (6 h, group $3 \mathrm{~b})$, and sexual stimulation with pheromone and females $(\mathrm{P}+\mathrm{F}$, group 1$)$. Magnification: $50 \times$. 

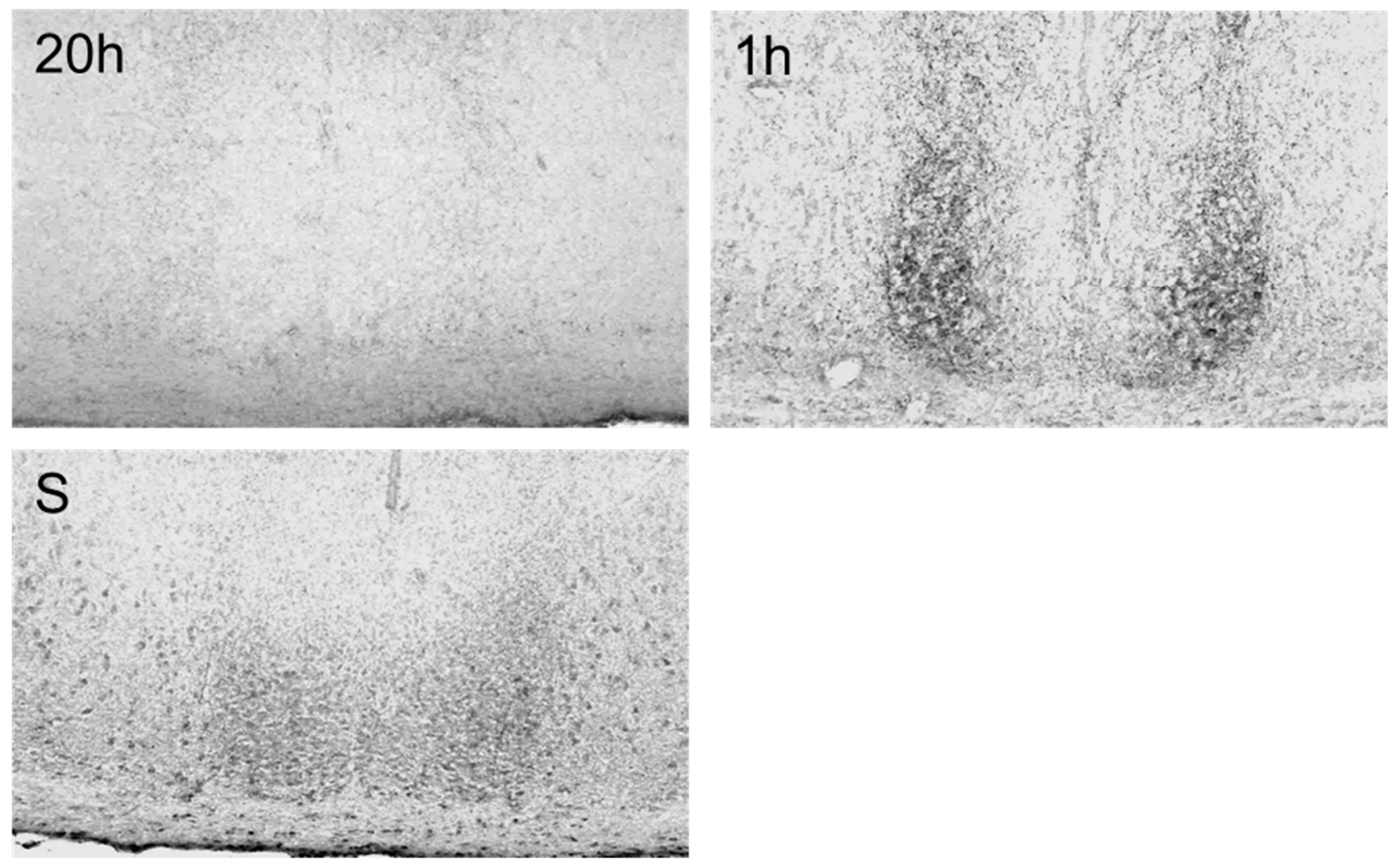

Figure A5. Gastrin releasing peptide immunoreactivity in the suprachiasmatic nuclei of Syrian hamsters. Comparison between $20 \mathrm{~h}$ manual sleep deprivation (20 h, group 3c), $1 \mathrm{~h}$ manual sleep deprivation (1 h, group 3a) and sleep (S, group 5). Magnification: $50 \times$.
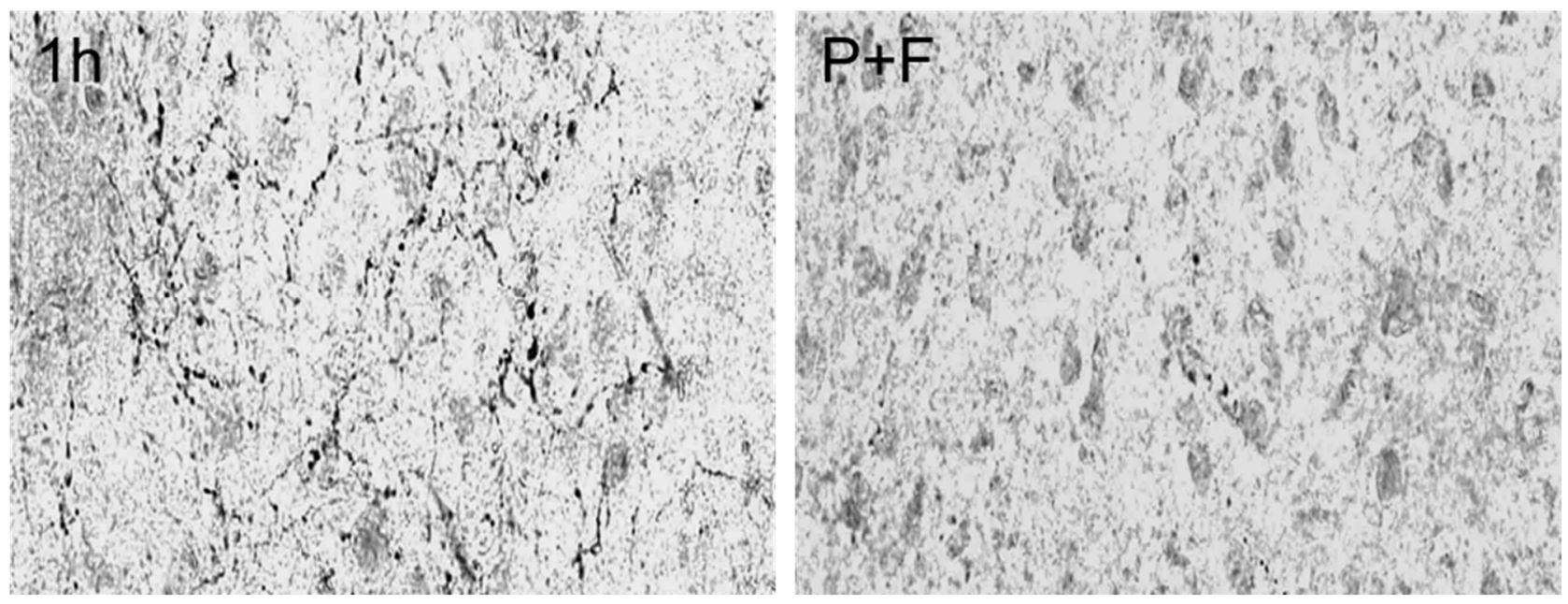

Figure A6. Substance P immunoreactivity in the suprachiasmatic nucleus of Syrian hamsters. Comparison between $1 \mathrm{~h}$ manual sleep deprivation $(1 \mathrm{~h}$, group $3 \mathrm{a})$ and sexual stimulation with pheromone and females (P+F, group 1). Magnification: $200 \times$. 

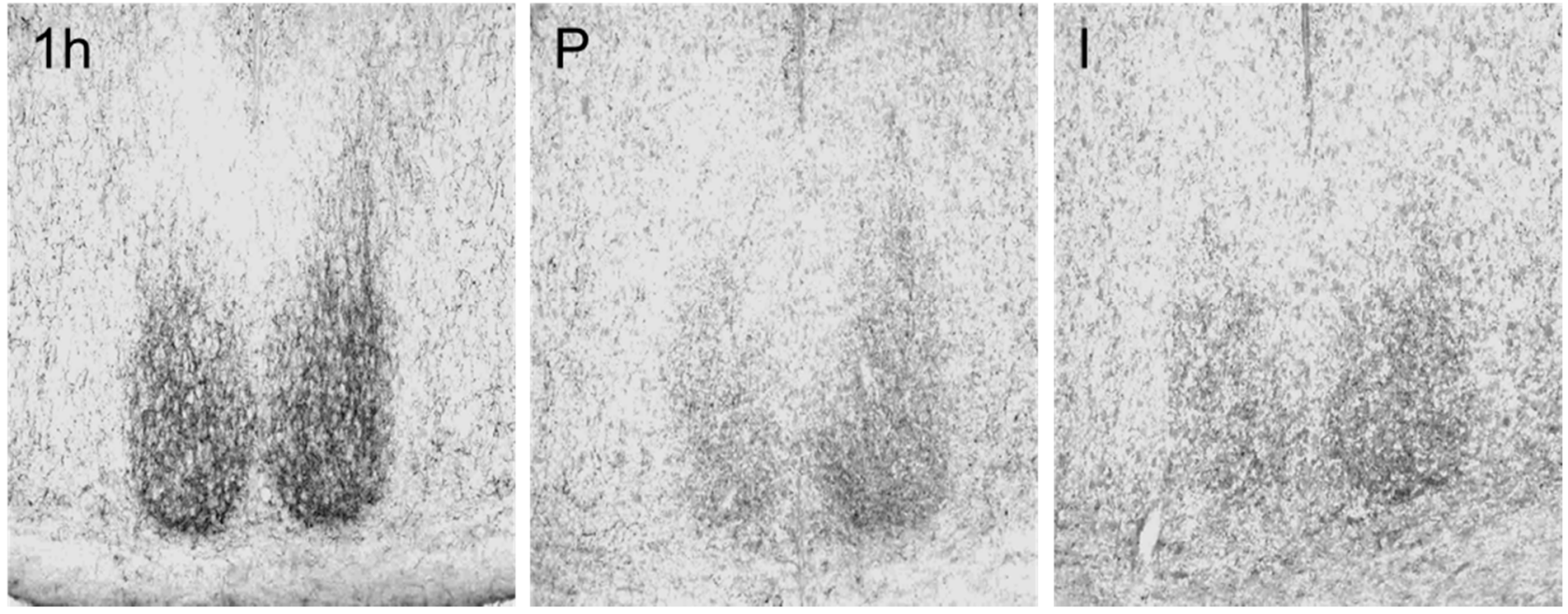

Figure A7. Neuropeptide Y immunoreactivity in the suprachiasmatic nucleus of Syrian hamsters. Comparison between $1 \mathrm{~h}$ manual sleep deprivation (1 h, group 3a), sexual stimulation with pheromone (P, group 2), and immobilization stress (I, group 4). Magnification: $40 \times$.
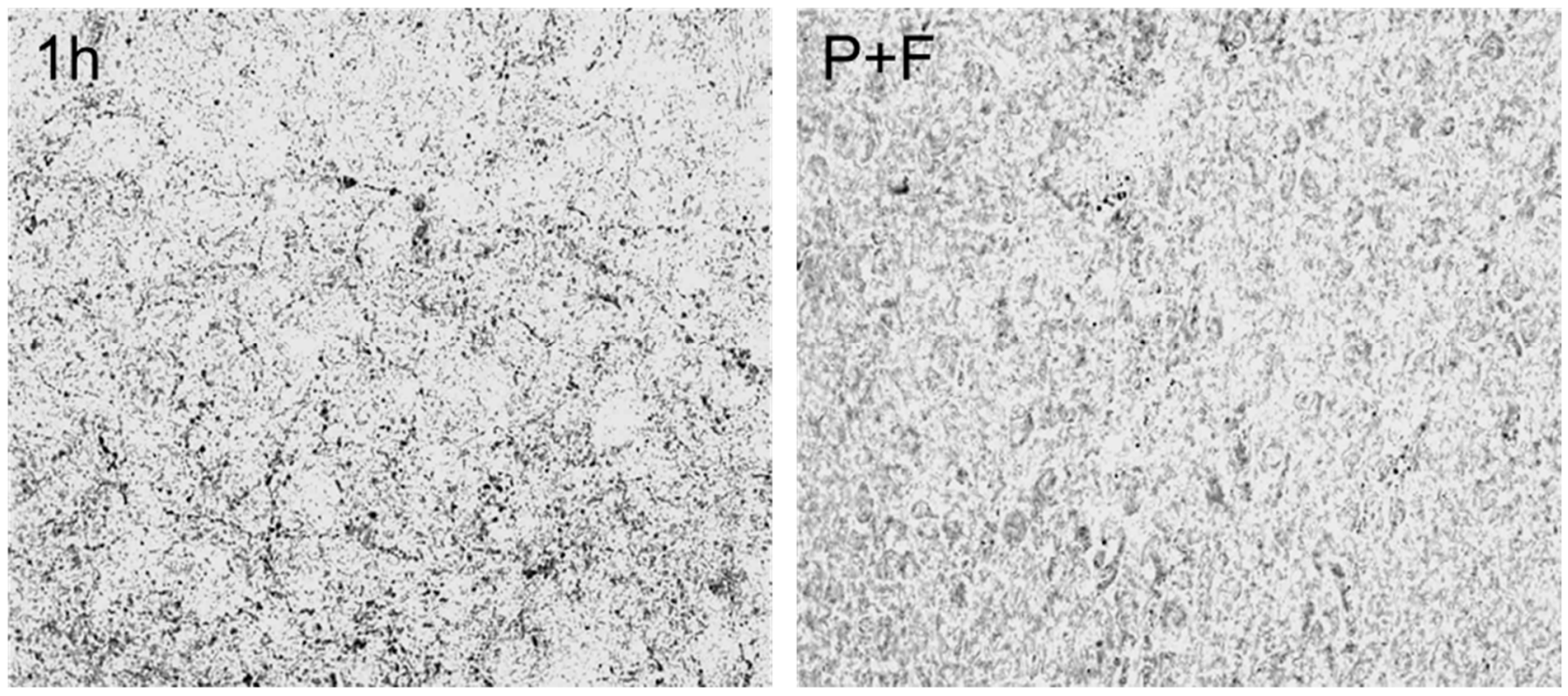

Figure A8. Methionin-enkephalin immunoreactivity in the suprachiasmatic nucleus of Syrian hamsters. Comparison between $1 \mathrm{~h}$ manual sleep deprivation $(1 \mathrm{~h}$, group $3 \mathrm{a})$ and sexual stimulation with pheromone and females $(\mathrm{P}+\mathrm{F}$, group 1$)$. Magnification: $200 \times$. 

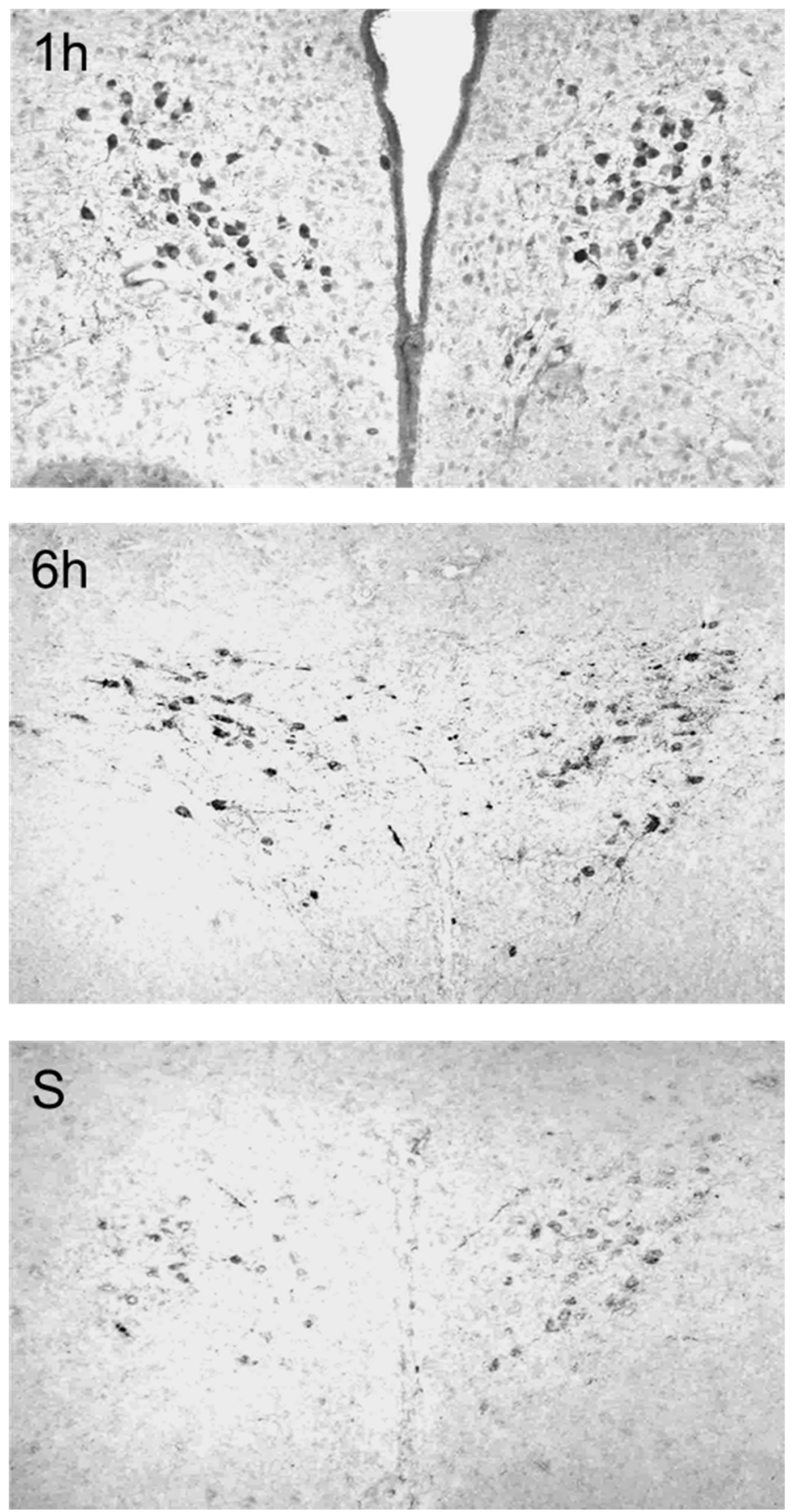

Figure A9. Oxytocin immunoreactivity in the paraventricular nuclei of Syrian hamsters. Comparison among $1 \mathrm{~h}$ manual sleep deprivation (1 h, group 3a), $6 \mathrm{~h}$ manual sleep deprivation (6 h, group $3 \mathrm{~b}$ ) and sleep (S, group 5). Magnification: $80 \times$. 

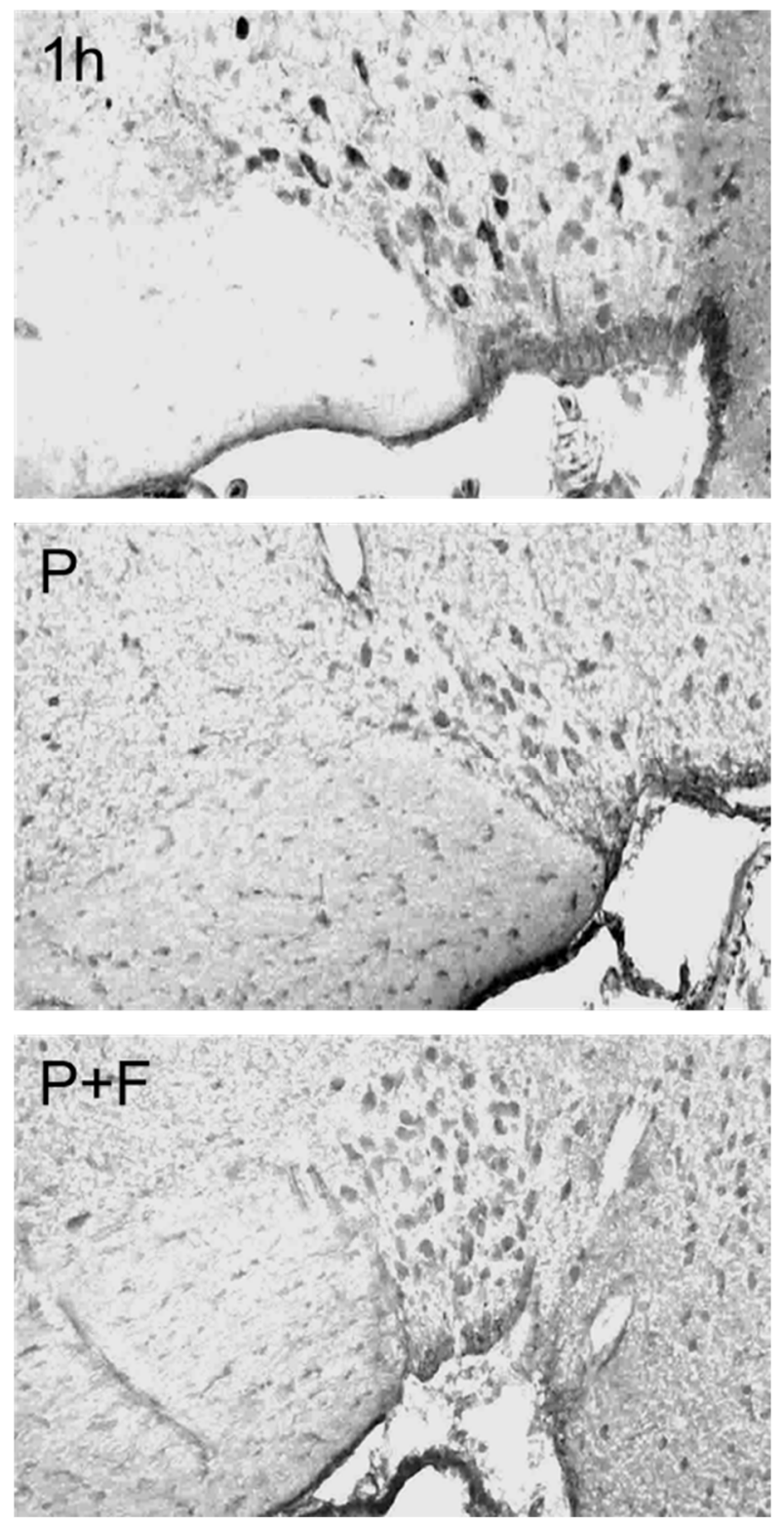

Figure A10. Oxytocin immunoreactivity in the supraoptic nucleus of Syrian hamsters. Comparison between $1 \mathrm{~h}$ manual sleep deprivation (1 h, group $3 \mathrm{a})$, sexual stimulation with pheromone (P, group 2), and sexual stimulation with pheromone and females $(\mathrm{P}+\mathrm{F}$, group 1$)$. Magnification: $80 \times$. 

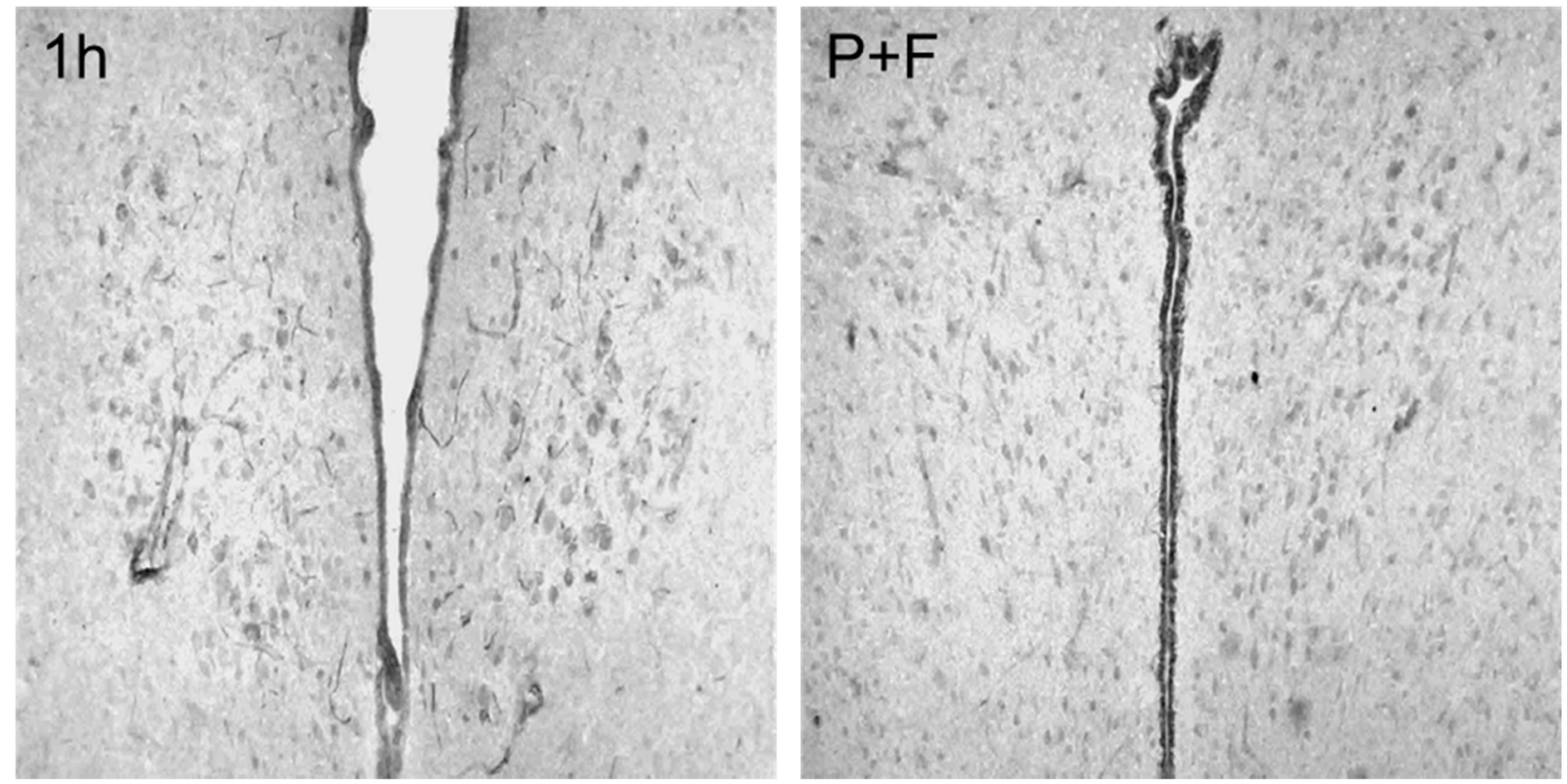

Figure A11. Androgen-receptor immunoreactivity in the paraventricular nuclei of Syrian hamsters. Comparison between $1 \mathrm{~h}$ manual sleep deprivation $(1 \mathrm{~h}$, group $3 \mathrm{a})$ and sexual stimulation with pheromone and females $(\mathrm{P}+\mathrm{F}$, group 1$)$. Magnification: $80 \times$.
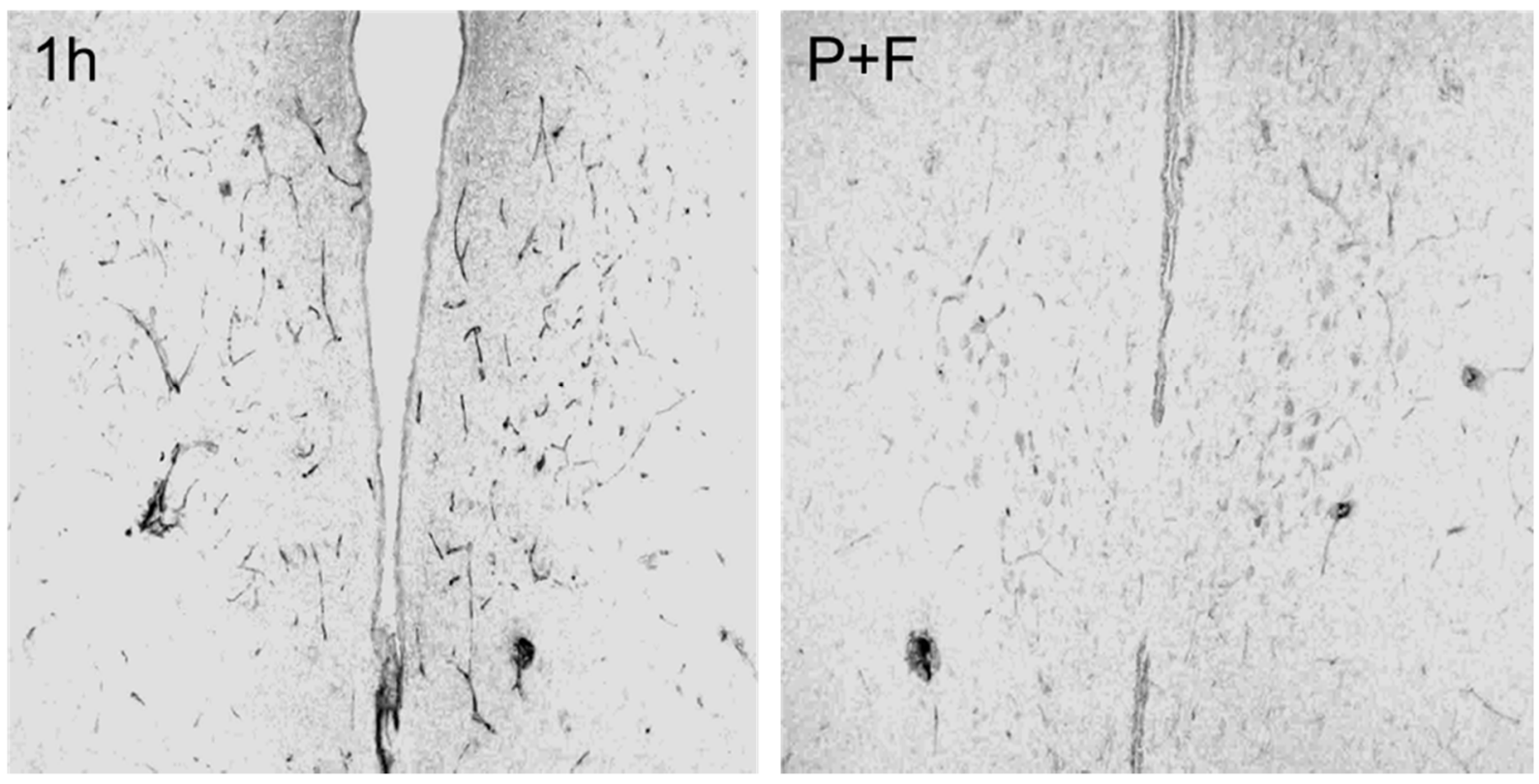

Figure A12. Estrogen-receptor immunoreactivity in the paraventricular nuclei of Syrian hamsters. Comparison between $1 \mathrm{~h}$ manual sleep deprivation $(1 \mathrm{~h}$, group $3 \mathrm{a})$ and sexual stimulation with pheromone and females $(\mathrm{P}+\mathrm{F}$, group 1$)$. Magnification: $50 \times$. 

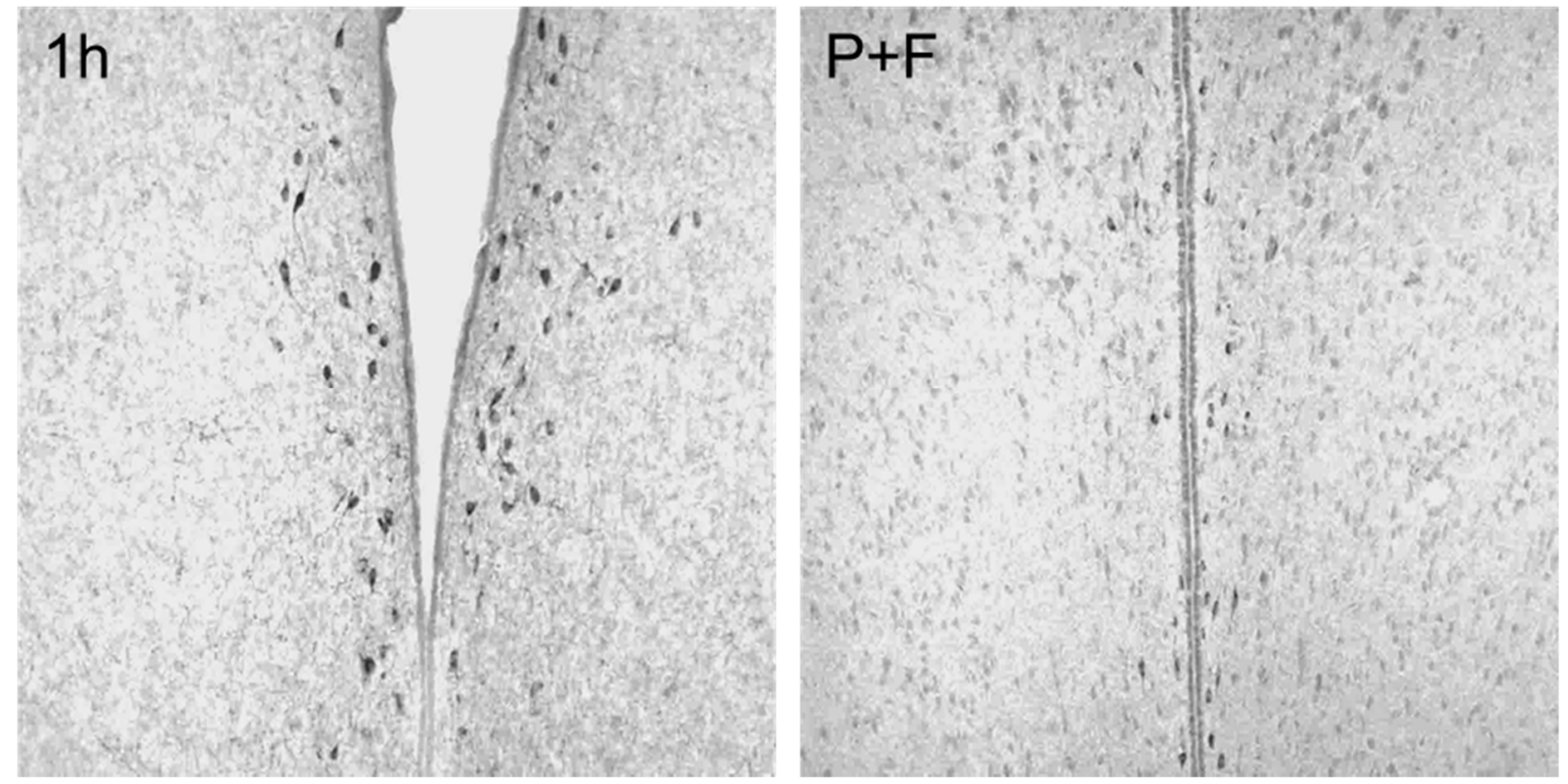

Figure A13. Somatostatin immunoreactivity in the medial periventricular nuclei of Syrian hamsters. Comparison between $1 \mathrm{~h}$ manual sleep deprivation $(1 \mathrm{~h}$, group $3 \mathrm{a})$ and sexual stimulation with pheromone and females $(\mathrm{P}+\mathrm{F}$, group 1$)$. Magnification: $50 \times$.
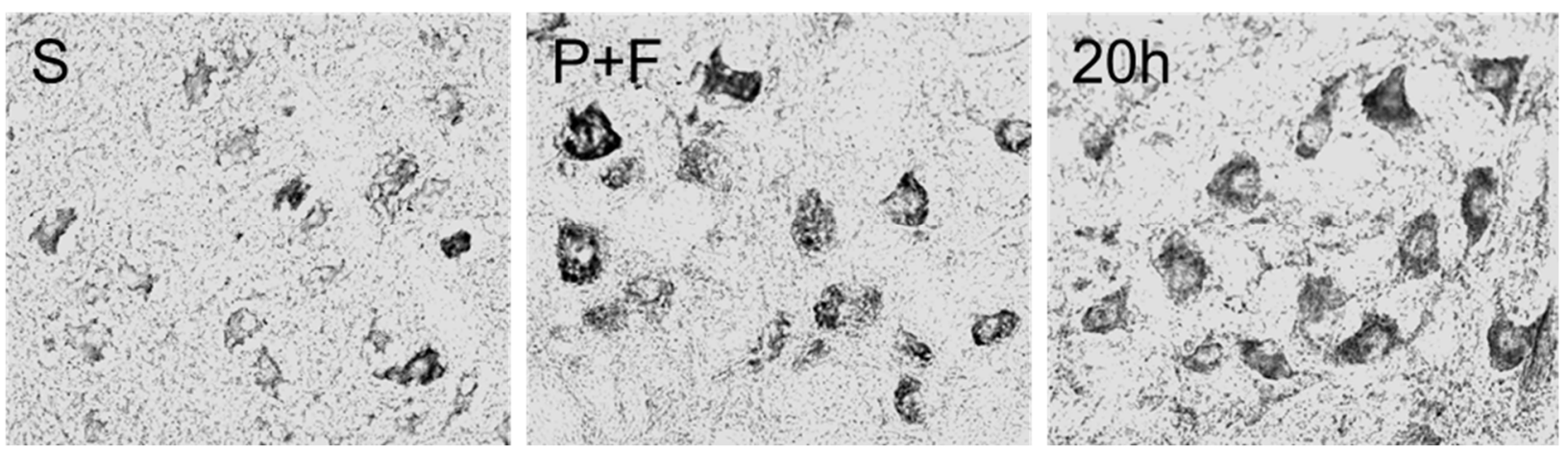

Figure A14. Dopamine $\beta$-hydroxylase immunoreactivity in area 7 of the brainstem of Syrian hamsters. Comparison between sleep (S, group 5), sexual stimulation with pheromone and females $(\mathrm{P}+\mathrm{F}$, group 1$)$, and $20 \mathrm{~h}$ manual sleep deprivation (20 $\mathrm{h}$, group 3c). Magnification: $200 \times$. 

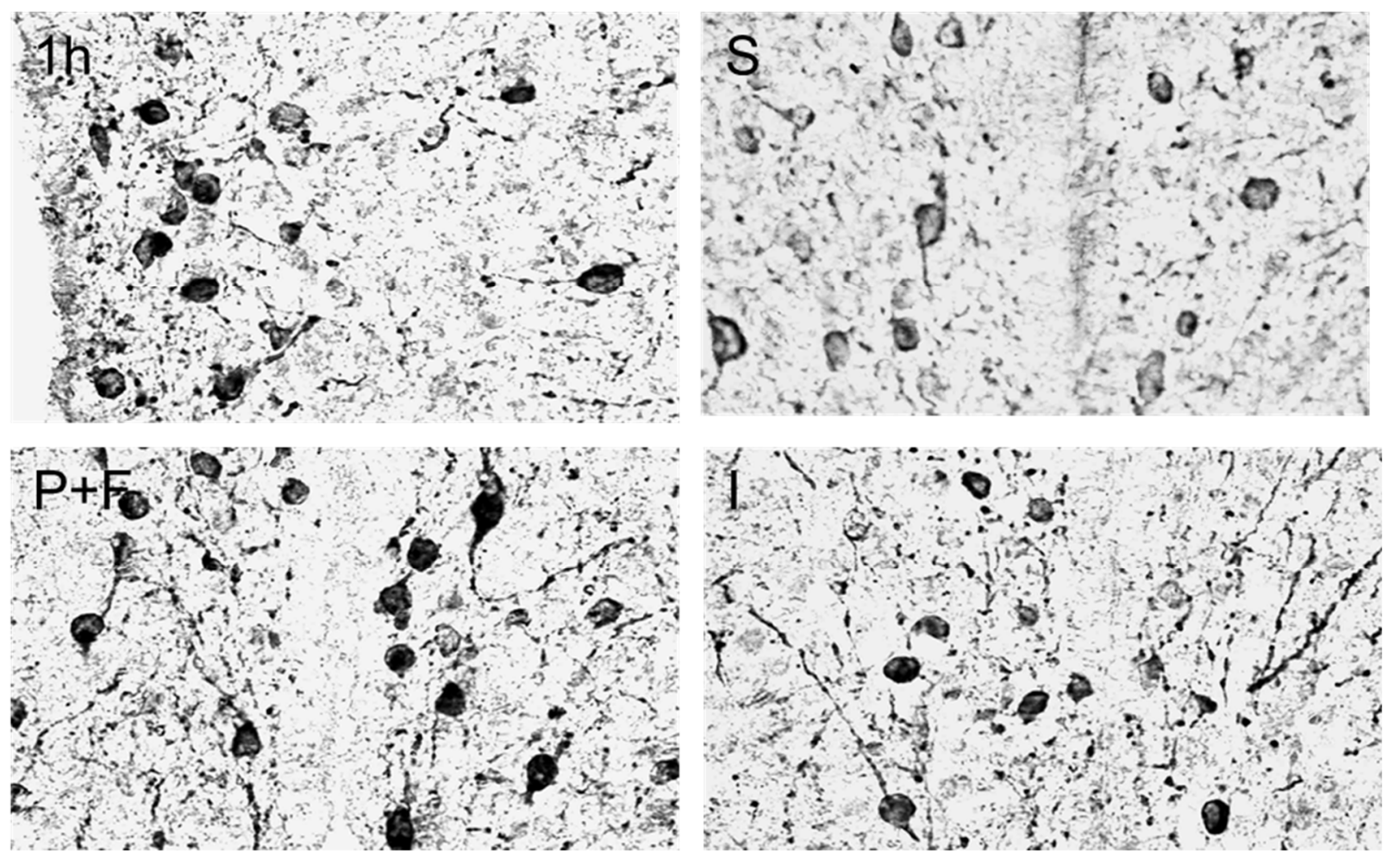

Figure A15. Tyrosine-hydroxylase immunoreactivity in the infundibular nucleus of Syrian hamsters. Comparison between $1 \mathrm{~h}$ manual sleep deprivation (1 h, group 3a), sleep ( , group 5), sexual stimulation with pheromone and females (P+F, group 1) and immobilization stress (I, group 4). Magnification: $200 \times$.

\section{References}

1. Pedersen, C.A.; Boccia, M.L. Vasopressin interactions with oxytocin in the control of female sexual behavior. Neuroscience 2006, 139, 843-851. [CrossRef] [PubMed]

2. Carter, C.S. Oxytocin and sexual behavior. Neurosci. Biobehav. Rev. 1992, 16, 131-144. [CrossRef]

3. Swaab, D.F. The Role of Hypothalamus and Endocrine System in Sexuality. In Biological Substrates of Human Sexuality; Hyde, J.S., Ed.; American Psychological Association: Washington, DC, USA, 2005; pp. 21-74. [CrossRef]

4. Wood, R.I.; Williams, S.J. Steroidal control of male hamster sexual behaviour in Me and MPOA: Effects of androgen dose and tamoxifen. Physiol. Behav. 2001, 72, 727-733. [CrossRef]

5. Rampin, O.; Jerome, N.; Suaudeau, C. Proerectile effects of apomorphine in mice. Life Sci. 2003, 72, 2329-2336. [CrossRef]

6. Azizi, V.; Oryan, S.; Khazali, H.; Hosseini, A. Central injection of neuropeptide Y modulates sexual behavior in male rats: Interaction with GnRH and kisspeptin/neurokinin B/dynorphin. Int. J. Neurosci. 2020, 20, 780-788.

7. Moreira, N.; Sandini, T.M.; Reis-Silva, T.M.; Navas-Suáresz, P.; Auada, A.V.V.; Lebrun, I.; Flório, J.C.; Bernardi, M.M.; Spinosa, H.S. Ivermectin reduces motor coordination, serum testosterone, and central neurotransmitter levels but does not affect sexual motivation in male rats. Reprod. Toxicol. 2017, 74, 195-203. [CrossRef] [PubMed]

8. van Furth, W.R.; van Ree, J.M. Sexual motivation: Involvement of endogenous opioids in the ventral tegmental area. Brain Res. 1996, 279, 20-28. [CrossRef]

9. Kapicioglu, S.; Mollamehmetoglu, M.; Kutlu, N.; Can, G.; Ozgur, G.K. Inhibition of penile erection in rats by a long-acting somatostatin analogue, octreotide (SMS 201-995). Br. J. Urol. 1998, 81, 142-145. [CrossRef]

10. Hull, E.M.; Lorrain, D.S.; Du, J.; Matuszewich, L.; Lumley, L.A.; Putnam, S.K.; Moses, J. Hormone-neurotransmitter interactions in the control of sexual behavior. Behav. Brain Res. 1999, 105, 105-116. [CrossRef]

11. Weaver, D.R. The suprachiasmatic nucleus: A 25-year retrospective. J. Biol. Rhythm. 1998, 13, 100-112. [CrossRef]

12. Ottesen, B.; Ulrichsen, H.; Fahrenkrug, J.; Larsen, J.J.; Wagner, G.; Schierup, L.; Sondergaard, F. Vasoactive intestinal polypeptide and the female genital tract: Relationship to reproductive phase and delivery. Am. J. Obstet. Gynecol. 1982, 143, 414-420. [CrossRef]

13. Yamada, K.; Wada, E.; Wada, K. Female gastrin-releasing peptide receptor (GRP-R)-deficient mice exhibit altered social preference for male conspecifics: Implications for GRP/GRP-R modulation of GABAergic function. Brain Res. 2001, 894, 281-287. [CrossRef]

14. Sakamoto, H. Brain-spinal cord neural circuits controlling male sexual function and behavior. Neurosci. Res. 2012, 72, 103-116. [CrossRef] 
15. Vrang, N.; Larsen, P.J.; Mikkelsen, J.D. Direct projection from the suprachiasmatic nucleus to hypophysiotrophic corticotropinreleasing factor immunoreactive cells in the paraventricular nucleus of the hypothalamus demonstrated by means of Phaseolus vulgaris-leucoagglutinin tract tracing. Brain Res. 1995, 684, 61-69. [CrossRef]

16. Cui, L.N.; Saeb-Parsy, K.; Dyball, R.E. Neurones in the supraoptic nucleus of the rat are regulated by a projection from the suprachiasmatic nucleus. J. Physiol. 1997, 502 Pt 1, 149-159. [CrossRef]

17. Vincent, S.R.; McIntosh, C.H.; Buchan, A.M.; Brown, J.C. Central somatostatin systems revealed with monoclonal antibodies. J. Comp. Neurol. 1985, 238, 169-186. [CrossRef] [PubMed]

18. Glass, J.D.; DiNardo, L.A.; Ehlen, J.C. Dorsal raphe nuclear stimulation of SCN serotonin release and circadian phase-resetting. Brain Res. 2000, 859, 224-232. [CrossRef]

19. Glass, J.D.; Grossman, G.H.; Farnbauch, L.; DiNardo, L. Midbrain raphe modulation of nonphotic circadian clock resetting and 5-HT release in the mammalian suprachiasmatic nucleus. J. Neurosci. 2003, 23, 7451-7460. [CrossRef]

20. Pudovkina, O.L.; Cremers, T.I.; Westerink, B.H. The interaction between the locus coeruleus and dorsal raphe nucleus studied with dual-probe microdialysis. Eur. J. Pharmacol. 2002, 445, 37-42. [CrossRef]

21. González, M.M.; Aston-Jones, G. Circadian regulation of arousal: Role of the noradrenergic locus coeruleus system and light exposure. Sleep 2006, 29, 1327-1336. [CrossRef]

22. Deboer, T.; Détári, L.; Meijer, J.H. Long term effects of sleep deprivation on the mammalian circadian pacemaker. Sleep 2007, 30, 257-262. [CrossRef] [PubMed]

23. Petrulis, A.; Johnston, R.E. A reevaluation of dimethyl disulfide as a sex attractant in golden hamsters. Physiol. Behav. 1995, 57, 779-784. [CrossRef]

24. Briand, L.; Huet, J.C.; Perez, V.; Lenoir, G.; Nespoulous, C.; Boucher, Y.; Trotier, D.; Pernollet, J.C. Odorant and pheromone binding by aphrodisn, a hamster aphrodisiac protein. FEBS Lett. 2000, 476, 179-185. [CrossRef]

25. Jang, T.; Singer, A.G.; O'Connell, R.J. Induction of $c$-fos in hamster accessory olfactory bulbs by natural and cloned aphrodisin. Neuroreport 2001, 12, 449. [CrossRef]

26. Naylor, E.; Buxton, O.M.; Bergmann, B.M.; Easton, A.; Phyllis, C.; Zee, P.C.; Turek, F.W. Effects of Aging on Sleep in the Golden Hamster. Sleep 1998, 21, 687-693. [CrossRef]

27. Mägert, H.J.; Cieslak, A.; Alkan, O.; Lüscher, B.; Kauffels, W.; Forssmann, W.G. The golden hamster aphrodisin gene. Structure, expression in parotid glands of female animals, and comparison with a similar murine gene. J. Biol. Chem. 1999, 274, 444-450. [CrossRef]

28. Bielfeld, H. Der Goldhamster. 2. Auflage. Ulmer Stuttgart 1992, 72-74. Available online: http://d-nb.info/930466705 (accessed on 26 August 2021).

29. Schilling, J.; Nürnberger, F. Dynamic changes in the immunoreactivity of neuropeptide systems of the suprachiasmatic nuclei in golden hamsters during the sleep-wake cycle. Cell Tissue Res. 1998, 294, 233-241. [CrossRef]

30. Zamboni, L.; De Martino, C. Buffered picric acid-formaldehyde: A new rapid fixative for electron microscopy. J. Cell Biol. 1967, $35,148 \mathrm{~A}$.

31. Nürnberger, F.; Schindler, C.U.; Kriete, A. The serotonin-immunoreactive system of the suprachiasmatic nucleus in the hibernating ground squirrel, Spermophilus richardsonii. Cell Tissue Res. 1989, 256, 593-599. [CrossRef] [PubMed]

32. Cardiff, R.D.; Miller, C.H.; Munn, R.J. Manual immunohistochemistry staining of mouse tissues using the avidin-biotin complex (ABC) technique. Cold Spring Harb. Protoc. 2014, 2014, 659-662. [CrossRef] [PubMed]

33. Card, J.P.; Moore, R.Y. The suprachiasmatic nucleus of the golden hamster: Immunohistochemical analysis of cell and fiber distribution. Neuroscience 1984, 13, 415-431. [CrossRef]

34. Moore, R.Y.; Speh, J.C.; Leak, R.K. Suprachiasmatic nucleus organization. Cell Tissue Res. 2002, 309, 89-98. [CrossRef] [PubMed]

35. Engel, S. Camera lucida tracings in medical research. Med. Biol. Illus. 1955, 5, 71-74. [PubMed]

36. Forer, A. A camera-lucida procedure for low-contrast material. J. R. Microsc. Soc. 1968, 88, 611-613. [CrossRef]

37. Andy, O.J.; Kurimoto, T.; Velamati, S.; Peeler, D. Limbic stimulation-induced hypersexuality. Levels of sexual drive. Pavlov. J. Biol. Sci. 1983, 18, 22-35.

38. Tsuchiya, T.; Horii, I. Different effects of acute and chronic immobilization stress on plasma testosterone levels in male Syrian hamsters. Psychoneuroendocrinology 1995, 20, 95-102. [CrossRef]

39. Srivastava, R.K.; Taylor, M.R.; Mann, D.R. Effect of immobilization stress on plasma luteinizing hormone, testosterone, and corticosterone concentrations and on 3 beta-hydroxysteroid dehydrogenase activity in the testes of adult rats. Proc. Soc. Exp. Biol. Med. 1993, 204, 231-235. [CrossRef]

40. Demura, R.; Suzuki, T.; Nakamura, S.; Komatsu, H.; Odagiri, E.; Demura, H. Effect of immobilization stress on testosterone and inhibin in male rats. J. Androl. 1989, 10, 210-213. [CrossRef] [PubMed]

41. Kalsbeek, A.; Teclemariam-Mesbah, R.; Pevet, P. Efferent projections of the suprachiasmatic nucleus in the golden hamster (Mesocricetus auratus). J. Comp. Neurol. 1993, 332, 293-314. [CrossRef]

42. Jirikowski, G.F.; Caldwell, J.D.; Haussler, H.U.; Pedersen, C.A. Mating alters topography and content of oxytocin immunoreactivity in male mouse brain. Cell Tissue Res. 1991, 266, 399-403. [CrossRef] [PubMed]

43. Smock, T.; Albeck, D.; Stark, P. A peptidergic basis for sexual behaviour in mammals. Prog. Brain Res. 1998, 119, 467-481. [PubMed] 
44. Sodersten, P.; Boer, G.J.; De Vries, G.J.; Buijs, R.M.; Melin, P. Effects of vasopressin on female sexual behaviour in male rats. Neurosci. Lett. 1986, 69, 188-191. [CrossRef]

45. Jezova, D.; Skultetyova, I.; Tokarev, D.I.; Bakos, P.; Vigas, M. Vasopressin and oxytocin in stress. Ann. N. Y. Acad. Sci. 1995, 771, 192-203. [CrossRef]

46. de Goeij, D.C.; Jezova, D.; Tilders, F.J. Repeated stress enhances vasopressin synthesis in corticotropin releasing factor neurons in the paraventricular nucleus. Brain Res. 1992, 577, 165-168. [CrossRef]

47. Segraves, R.T. Effects of psychotropic drugs on human erection and ejaculation. Arch. Gen. Psychiatry 1989, 46, 275-284. [CrossRef] [PubMed]

48. Levin, R.J. VIP, vagina, clitoral and periurethral glans—an update on human female genital arousal. Exp. Clin. Endocrinol. 1991, 98, 61-69. [CrossRef]

49. Gavalda, A.; Benyassi, A.; Arancibia, S.; Armario, A. Chronic but not acute exposure to stress is associated with hypothalamic vasoactive intestinal polypeptide (VIP) release into median eminence. J. Neuroendocrinol. 1993, 5, 421-425. [CrossRef]

50. Iwanaga, T.; Ohtsuka, H.; Adachi, I.; Fujita, T. GRP (gastrin-releasing peptide)-containing nerves in the rat stomach and stress-induced depletion of their synaptic vesicles. An electron microscope study. Arch. Histol. Cytol. 1991, 54, 573-580. [CrossRef]

51. Bitran, D.; Miller, S.A.; McQuade, D.B.; Leipheimer, R.E.; Sachs, B.D. Inhibition of sexual reflexes by lumbosacral injection of a GABA-B agonist in the male rat. Pharmacol. Biochem. Behav. 1988, 31, 657-666. [CrossRef]

52. Qureshi, G.A.; Bednar, I.; Forsberg, B.G.; Sodersten, P. GABA inhibits sexual behaviour in female rats. Neuroscience 1988, 27, 169-174. [CrossRef]

53. Fernandez-Guasti, A.; Larsson, K.; Beyer, C. Effect of bicuculline on sexual activity in castrated male rats. Physiol. Behav. 1986, 36, 235-237. [CrossRef]

54. Navarro Becerra, N.; Munaro, N.I. Gamma-Aminobutyric acid activity in the olfactory bulb of the rat during the sexual cycle and response to olfactory stimuli. Can. J. Physiol. Pharmacol. 1992, 70, 922-925. [CrossRef]

55. Yoneda, Y.; Kanmori, K.; Ida, S.; Kuriyama, K. Stress-induced alterations in metabolism of gamma-aminobutyric acid in rat brain. J. Neurochem. 1983, 40,350-356. [CrossRef]

56. Otero Losada, M.E. Acute stress and GABAergic function in the rat brain. Br. J. Pharmacol. 1989, 96, 507-512. [CrossRef] [PubMed]

57. Curie, T.; Maret, S.; Emmenegger, Y.; Franken, P. In Vivo Imaging of the Central and Peripheral Effects of Sleep Deprivation and Suprachiasmatic Nuclei Lesion on PERIOD-2 Protein in Mice. Sleep 2015, 38, 1381-1394. [CrossRef] [PubMed]

58. Mongrain, V.; La Spada, F.; Curie, T.; Franken, P. Sleep loss reduces the DNA-binding of BMAL1, CLOCK, and NPAS2 to specific clock genes in the mouse cerebral cortex. PLoS ONE 2011, 6, e26622. [CrossRef] [PubMed]

59. Wisor, J.P.; O’Hara, B.F.; Terao, A.; Selby, C.P.; Kilduff, T.S.; Sancar, A.; Edgar, D.M.; Franken, P. A role for cryptochromes in sleep regulation. BMC Neurosci. 2002, 3, 20. [CrossRef]

60. Yagita, K.; Yamaguchi, S.; Tamanini, F.; van Der Horst, G.T.; Hoeijmakers, J.H.; Yasui, A.; Loros, J.J.; Dunlap, J.C.; Okamura, H. Dimerization and nuclear entry of mPER proteins in mammalian cells. Genes Dev. 2000, 14, 1353-1363. [PubMed]

61. Herzog, E.D.; Takahashi, J.S.; Block, G.D. Clock controls circadian period in isolated suprachiasmatic nucleus neurons. Nat. Neurosci. 1998, 1, 708-713. [CrossRef] [PubMed]

62. Varcoe, T.J.; Kennaway, D.J.; Voultsios, A. Activation of 5-HT2C receptors acutely induces Per gene expression in the rat suprachiasmatic nucleus at night. Brain Res. Mol. Brain Res. 2003, 119, 192-200. [CrossRef]

63. Dornan, W.A.; Malsbury, C.W.; Penney, R.B. Facilitation of lordosis by injection of substance P into the midbrain central gray. Neuroendocrinology 1987, 45, 498-506. [CrossRef] [PubMed]

64. Takayama, H.; Ota, Z.; Ogawa, N. Effect of immobilization stress on neuropeptides and their receptors in rat central nervous system. Regul. Pept. 1986, 15, 239-248. [CrossRef]

65. Iumatov, E.A.; Poppai, M.; Ratsak, R. Changes in the substance P content of the blood and hypothalamus during experimental emotional stress. Biull. Eksp. Biol. Med. 1985, 99, 397-399. [PubMed]

66. Gray, T.S.; Morley, J.E. Neuropeptide Y: Anatomical distribution and possible function in the mammalian nervous system. Life Sci. 1986, 38, 389-401. [CrossRef]

67. Corder, R.; Castagne, V.; Rivet, J.M.; Mormede, P.; Gaillard, R.C. Central and peripheral effects of repeated stress and high NaCl diet on neuropeptide Y. Physiol. Behav. 1992, 52, 205-210. [CrossRef]

68. Pralong, F.P.; Corder, R.; Gaillard, R.C. The effects of chronic glucocorticoid excess, adrenalectomy and stress on neuropeptide Y in individual rat hypothalamic nuclei. Neuropeptides 1993, 25, 223-231. [CrossRef]

69. Makino, S.; Baker, R.A.; Smith, M.A.; Gold, P.W. Differential regulation of neuropeptide Y mRNA expression in the arcuate nucleus and locus coeruleus by stress and antidepressants. J. Neuroendocrinol. 2000, 12, 387-395. [CrossRef]

70. Grossman, G.H.; Mistlberger, R.E.; Antle, M.C.; Ehlen, J.C.; Glass, J.D. Sleep deprivation stimulates serotonin release in the suprachiasmatic nucleus. Neuroreport 2000, 11, 1929-1932. [CrossRef] [PubMed]

71. Alfaro-Rodríguez, A.; González-Piña, R.; González-Maciel, A.; Arch-Tirado, E. Serotonin and 5-hydroxy-indole-acetic acid contents in dorsal raphe and suprachiasmatic nuclei in normal, malnourished and rehabilitated rats under $24 \mathrm{~h}$ of sleep deprivation. Brain Res. 2006, 1110, 95-101. [CrossRef] [PubMed]

72. Kvetnanský, R.; Palkovits, M.; Mitro, A.; Torda, T.; Mikulaj, L. Catecholamines in individual hypothalamic nuclei of acutely and repeatedly stressed rats. Neuroendocrinology 1977, 23, 257-267. [CrossRef] 
73. Carmichael, M.S.; Humbert, R.; Dixen, J.; Palmisano, G.; Greenleaf, W.; Davidson, J.M. Plasma oxytocin increases in the human sexual response. J. Clin. Endocrinol. Metab. 1987, 64, 27-31. [CrossRef]

74. Hillegart, V.; Alster, P.; Uvnas-Moberg, K.; Ahlenius, S. Sexual motivation promotes oxytocin secretion in male rats. Peptides 1998, 19, 39-45. [CrossRef]

75. Blaicher, W.; Gruber, D.; Bieglmayer, C.; Blaicher, A.M.; Knogler, W.; Huber, J.C. The role of oxytocin in relation to female sexual arousal. Gynecol. Obstet. Investig. 1999, 47, 125-126. [CrossRef]

76. Melis, M.R.; Spano, M.S.; Succu, S.; Argiolas, A. The oxytocin antagonist d(CH2)5Tyr(Me)2-Orn8-vasotocin reduces non-contact penile erections in male rats. Neurosci. Lett. 1999, 265, 171-174. [CrossRef]

77. Melis, M.R.; Argiolas, A. Central oxytocinergic neurotransmission: A drug target for the therapy of psychogenic erectile dysfunction. Curr. Drug Targets 2003, 4, 55-66. [CrossRef]

78. Carmichael, M.S.; Warburton, V.L.; Dixen, J.; Davidson, J.M. Relationships among cardiovascular, muscular, and oxytocin responses during human sexual activity. Arch. Sex. Behav. 1994, 23, 59-79. [CrossRef] [PubMed]

79. Jezova, D.; Michajlovskij, N.; Kvetnansky, R.; Makara, G.B. Paraventricular and supraoptic nuclei of the hypothalamus are not equally important for oxytocin release during stress. Neuroendocrinology 1993, 57, 776-781. [CrossRef]

80. Kato, T.; Montplaisir, J.M.; Lavigne, G.J. Experimentally induced arousals during sleep: A matchimg paradigm. J. Sleep Res. 2004, 13, 229-238. [CrossRef]

81. Zerbi, V.; Floriou-Servou, A.; Markicevic, M.; Vermieren, Y.; Sturman, O.; Privitera, M.; Ziegler, L.V.; Ferrari, K.D.; Weber, B.; DeDeyn, P.P.; et al. Rapid reconfiguration of the functional connectome after chemogenetic Locus coeruleus activation. Neuron 2019, 4, 702-718.e5. [CrossRef]

82. Viau, V.; Chu, A.; Soriano, L.; Dallman, F. Independent and overlapping effects of corticosterone and testosterone on corticotropinreleasing hormone and arginine vasopressin mRNA expression in the paraventricular nucleus of the hypothalamus and stressinduced adrenocorticotropic hormone release. J. Neurosci. 1999, 19, 6648-6693. [CrossRef]

83. Winsky-Sonnerer, R.; Yamanaka, A.; Diano, S.; Borok, E.; Roberts, A.J.; Sakurai, T.; Kilduff, T.S.; Horvath, T.L.; de Lecea, L. Interaction between the corticotropin-releasing factor system and hypocretins (Orexins): A novel circuit mediating stress response. J. Neurosci. 2004, 24, 11439-11448. [CrossRef] [PubMed]

84. Pieper, D.R.; Newman, S.W. Neural pathway from the olfactory bulbs regulating tonic gonadotropin secretion. Neurosci. Biobehav. Rev. 1999, 23, 555-562. [CrossRef]

85. Model, Z.; Butler, M.P.; LeSauter, J.; Silver, R. Suprachiasmatic nucleus as site of androgen action on circadian rhythms. Horm. Behav. 2015, 73, 1-7. [CrossRef] [PubMed]

86. Williamson, M.; Bingham, B.; Gray, M.; Innala, L.; Viau, V. The medial preoptic nucleus integrates the central influences of testosterone on the paraventricular nucleus of the hypothalamus and its extended circuitries. J. Neurosci. 2010, 30, 11762-11770. [CrossRef]

87. Staiger, J.F.; Nürnberger, F. The efferent connections of the lateral septal nucleus in the guinea pig: Projections to the diencephalon and brainstem. Cell Tissue Res. 1991, 264, 391-413. [CrossRef] [PubMed]

88. Torterolo, P.; Sampogna, S.; Morales, F.R.; Chase, M.H. MCH-containing neurons in the hypothalamus of the cat: Searching for a role in the control of sleep and wakefulness. Brain Res. 2006, 1119, 101-114. [CrossRef]

89. Lin, L.; Faraco, J.; Li, R.; Kadotani, H.; Rogers, W.; Lin, X.; Qiu, X.; de Jong, P.J.; Nishino, S.; Mignot, E. The sleep disorder canine narcolepsy is caused by a mutation in the hypocretin (orexin) receptor 2 gene. Cell 1999, 98, 273-408. [CrossRef] 